CHAPTER TWO

\title{
THE PLAIN-SPEAKING ENGLISHMAN
}

\section{A LANGUAGE IN FLUX}

The intense linguistic flux which characterised the sixteenth and seventeenth centuries raised urgent questions as to the direction that the vernacular was taking. These questions were articulated in print in a variety of ways. Humanist rhetoricians were concerned with the formal expression of public man; sceptics took issue with the so-called 'inkhorn' vocabulary of the scholarly world which was thought to be far too arcane for clarity. Antiquarians worried that the language was removing itself too far from its Saxonist roots, and translators could be at once eager and ambivalent about the very works they translated. ${ }^{1}$ In a particular way, the spoken word was contested and became, in the process, caught up in wider debates about identity. Speech, as Adam Fox has put it in his recent study of oral culture in England, provides 'a more immediate and sensitive insight into the mental world of a people than perhaps all other forms of expression' and it will thus enable a recovery of perceptions and assumptions about desirable and actual identities. ${ }^{2}$ Methodologically, the challenges of investigating this remain considerable. One is the issue of access, for all the historian can call upon in this domain is what people actually wrote about how English was or was not, should or should not be spoken: it is the problem, in James Obelkevich's memorable phrase, of 'conjur[ing] orality out of literacy', something achievable only through a certain amount of sleight of hand. ${ }^{3}$ Since any attempt to retrieve the spoken word

\footnotetext{
1 Wilson 1553; Peacham 1577; [Puttenham] 1589 are three of the most definitive rhetoric manuals of the day. Upon the vogue for and the reaction against recondite 'inkhorn' terms, which spilled out over the borders of the scholarly world see Barber 1976, pp. 81-90; Görlach 1991, pp. 161-162. The most extreme presentation of the antiquarian case comes from the pen of Richard Verstegan 1605. He had a complete reverence for monosyllabic native word units and a historically-based revulsion at foreign accretions. See Jones 1953, pp. 214-71 for extensive treatment of the antiquaries' views of the English language. George Pettie is an example of a translator who accepts that imports are the 'ready vvay to inrich our tongue, and make it copious' but also is ambivalent about Englishmen borrowing too much of their ways of being from abroad. Guazzo 1581, sigs. ijj ${ }^{\mathrm{r}}$, ijv.

${ }^{2}$ Fox 2000, p. 51 .

3 Obelkevich 1987 , p. 43.
} 
is thus channelled through a written medium of some sort, the analysis offered is of necessity at one remove. Nevertheless, the subject is accessible in four ways: first, in the vigorous endorsement of homespun speech and secondly, in its politicisation. We shall find that plain speech is not just the quality of private man but is construed as a constituent part of his public persona. Thirdly, there emerges a continuous critique of an alien and excessive habit of discourse, which is seen to detract from true Englishness. Lastly, in spreading the net more widely to include other forms of language, we shall find the beginnings of a discourse on national forms of gesture and deportment.

\section{The Cult of Homespun Speech}

The starting point for understanding concepts of plainness of speech is to understand contemporary concerns surrounding rhetoric. In the curriculum of the sixteenth century, the study of rhetoric acquired a new importance, partly owing to the growth of classical humanism and partly for the very practical reason that the vulgar tongue was being used in contexts where before Latin had been pre-eminent, and thus it too had to be developed as a tool of persuasion. But rhetoric, with its intentions to teach, to delight and to persuade could be highly problematic. It was not a transparent art. Subject to manipulation, it could hinder meaning and truthfulness by obfuscation and recourse to the arcane. Subject to fashions, it could indulge in far-fetched experiments, borrowing too much from other cultures. The English language could become ghettoised: polarised between a court and university language and a country language, a sophisticated and a common speech.

One of strongest defences of plainness is to be found in the work of an Elizabethan statesman-scholar, Thomas Wilson, who worried about the implications of all this. The Arte of Rhetorique is one of the earliest works on rhetoric written in English: first published in 1553, with a more complete edition in 1560 , it ran to eight editions and became very popular with those who sought after eloquence in speech. The work is conventionally interpreted as one of the classic expositions of rhetoric in the Tudor period, and rightly so, for it is with the theory and even more so, the practice of eloquence with which this eminent humanist, well-schooled in the writings of Cicero and Quintilian, is principally concerned. ${ }^{4}$ Yet,

${ }^{4}$ Cicero presented his fullest treatment of the subject in De Oratore; Quintilian in the Institutio Oratoria. Skinner 2002, II, pp. 264-285 treats of the Renaissance revival of classical rhetoric in England. 
there is a more contemporary battle being fought at the same time, not merely a reformulation of the classical ideals, and that is the battle against too much elitism and too little commonality in language. On one level, this is somewhat surprising because Wilson snobbishly disdained his Lincolnshire origins and much preferred to live in London and be at the centre of things. Nevertheless, in the section devoted to plainness which receives pride of place in his study of elocution (the art of apt expression), he is adamant about its value. The first lesson to be learned before anything else, he says is to speak 'as is commonly receiued'. That means no strange and inkhorn terms. It means unlearning a lot of what one has learned. This is a most emphatic statement and disarming in a work of its kind. He looks around at his contemporaries and sees a worrying disunity of speech-forms. What he notices and objects to is that 'difference of Englishe' that divides 'courte talke' from 'country speache', or, in another modality, the so-called 'learned' from the 'rude'. The choice facing English society is emphatic, he claims: either accept the two modes of language and its implied divisiveness or (and this is his preference) banish 'al such affected Rhetorique' and 'vse altogether one maner of language.' His solution, therefore, is not to educate the average country dweller in the fashionable rhetoric of the day, but to educate the elite in plain talk, in the 'new' purified rhetoric of the Protestant nation. Wilson, it may be added, was a committed believer in the new religion. There are those who think that rhetoric stands 'wholy vpon darke woordes' and think national standing is enhanced by abandoning the gold standard of plainness. This sort of 'fine Englishman' is the height of folly and he proceeds to ridicule him with some verve. He is convinced that all those cherished shibboleths of social distinction, propounded by the educated and the cultivated, should be abandoned in favour of plainness. ${ }^{5}$

It is a curious moment in a work on rhetoric that he should be so adamant against affected rhetoric. Of course, he does claim that he is being truly Ciceronian in insisting that one's meaning should be plain for all men to perceive. ${ }^{6}$ Nevertheless, one might raise the objection that he is being rather ambiguous, even hypocritical: surely he has spent the entire work fashioning the kind of man whose 'difference' from the commonality will be supremely evident in the way he speaks. He has been teaching an art - a veritable craft of speaking: how well does his endorsement of plainness sit with that? It is undeniably true that the two projects sit uneasily

5 Wilson 1553 , fos. $86^{\mathrm{r}}-87^{\mathrm{r}}$.

6 Wilson $1553,88^{\mathrm{r}}$. 
together, but then again, plainness is not necessarily 'plain' in a narrowly linguistic sense: there is a rhetorical nature of all appeals to and professions of it. Wilson's espousal of plainness is an ideal: he may not even be aware that his way of talking is not always accessible to the common man. Later, in his preface to the translation of Demosthenes' Orations, he does not mind being accused of using 'over bare' English: he declares it his intention 'to speake simply and plainly to the common people's understanding, than to overflouryshe with superfluous speech. ${ }^{7}$ Wilson's very plainness is rhetorical but it is no less important for that. The gold standard of plainness and simplicity is established in one of the major humanist texts of the period, and it is at moments like this - rather than in the more formal construction of the homo rhetoricus who was not clearly nationally delineated - that the desire to fashion a national community through language is quite clearly to be seen.

Wilson's target audience was elevated - the kind of audience who would read a book on rhetoric. They were the men who, after all, were most likely to assimilate affectations in their speech: their plainness was particularly open to question. Something of the same concern is evident in the courtesy literature which sought to fashion the English gentleman. For Henry Peacham, in his classic 1622 work on the subject, The Compleat Gentleman fashioning him absolut, speech was the 'character of a man'. He urged his readership to make use of the 'most familiar words' when he spoke and to avoid pomp and what he calls 'emptie furniture of phrase'. He thought it wise to 'lay downe your words one by one.' In outlining these principles, he followed Cicero's De Oratore very closely, unsurprising in one who had attended Trinity College, Cambridge and was then a schoolteacher at St Martin-in-the-Fields, so perhaps one should, in his case, downplay its Englishness in favour of its rather more patent classical humanism. Yet he is doing something different too. This text is not a mere regurgitation of classical principles in education. On the contrary, it is an example of what Anthony Grafton and Lisa Jardine have said about the new curriculum making headway in this period, that it was a highly politicized phenomenon, aimed at the ruling elites and serving their agenda. ${ }^{8}$ This text is politicised in the sense of being national in tone: the contemporary Englishman is not merely a resurrected figure from classical antiquity. Peacham hastens to say that acquiring a plain form of rhetoric in English is just as

\footnotetext{
7 Demosthenes 1570, sig. iiijv.

8 Grafton and Jardine 1986, xiv.
} 
essential as knowing Latin, and he explicitly warns against an 'apish and supserstitious imitation' of Tully. ${ }^{9}$

There is even more to be gleaned from Richard Brathwaite's similar endeavour several years later. The titles alone reveal the shift in emphasis, from the Peacham's Compleat Gentleman to the latter's English Gentleman. Brathwaite's definition of a gentleman is as a 'man of himselfe' and he is concerned throughout with creating a profile that supports this. According to this respectable JP and deputy lieutenant, the Englishman ought to maintain sobriety in speech on all occasions. He urges the young man to speak 'but not with affectation' and speak 'freely, yet with reservation', thus proposing a fine balance between the frank and the restrained which recalls Shagan's thesis on the rule of moderation. He warns of slavish sycophantic speech and bids his reader steer clear of 'this mimicke and apish action' which keeps 'small concurrence with the Postures of a Gentleman ' 10

He then goes on to emphasise that the speech of such a one should be 'free, native and generous', that is to say it should be emblematic of a whole national culture and history. We would do well to dwell on the full implications of this. Plain speech, in fact, is part of his defence of the older more authentic country values whose decline he deplores. He reserves special praise for those gentry who are not 'besotted' with fashions and foreign imitations and live in the countryside being hospitable hosts and good landlords. He notes that they are ridiculed as 'men of rusticke condition' and 'mere home-spun fellowes' whose values derogate from the fads which are supposed to constitute gentility. But he wants to emphasise that the contrary is true: these very men are the true English gentlemen worthy of their predecessors. It is a new (rural and nationalist) twist on the humanist dictum that virtue was true nobility. Vera nobilità lies in a virtuous identification with one's land, with one's country. 'Return to your Houses' he urges his readers: this can be understood on multiple levels. In later centuries, of course, the bluff independent gentleman, residing on his estate for much of the year would become a distinctively (and self-consciously) English phenomenon. In Brathwaite, the outlines of this ideal are already emerging. ${ }^{11}$

What does plain speech and a plain style of life reveal about the Englishman, according to Brathwaite? Above all, it reveals that he is free, that he is truly his own man. His convictions have been made clear to us

\footnotetext{
9 Peacham 1622, p. 42-43.

10 Brathwaite 1641 edn., p. 8, Brathwaite 1630, sig. Nnn ${ }^{\mathrm{r}}$; p. 87. Shagan 2011.

11 Brathwaite 1630 , pp. 87 . Brathwaite 1641 edn., p. 37.
} 
from the very start: already in the epistle dedicatory, we are given to know that his very title 'exempts him from servile bashfulness, being an English Gentleman'. It is a forceful statement of belief in the defining independence of the type. ${ }^{12}$ Nor was that conviction at all unusual: it seems to have been a commonplace that, in the words of John Stradling, the translator of Justus Lipsius, '[o]f all other nations our owne is most free, ingenious and open'. ${ }^{13}$ Considering how much the educated early-modern Englishman was in debt to antique ideals, the rejection of any form of behaviour connected with servility was inevitably going to be as much a part of the gentlemanly ideal as it was part of that of the Athenian citizen or the Roman freeman. Yet here we need to underline the fact that it is not just a matter of Brathwaite casually transposing a classical trope but of fully integrating it into a present-day national context where to act with servility meant to imitate foreigners, particularly upper-class foreigners with whom the elites would have the most contact. This is the imitation of which he speaks, this the kind of affectation. It is anathema to plainness.

There is, furthermore, a curious silence in both Peacham's and Brathwaite's works which makes them stand out in one fundamental sense from the general run of courtesy manuals in vogue in Europe at that time and this very silence has a bearing upon our theme. Neither of them develops to any notable degree the theme of grace in the Castiglionian sense of elegancy of speech and behaviour, which becomes in the French manuals of the following century, a full-blown art de plaire, with emphasis on personal 'souplesse' or flexibility. ${ }^{14}$ One could say that the European works reveal a sort of behavioural aesthetics which is simply not to be found in the English equivalents. The lynchpin of this aesthetic is Castiglione's concept of sprezzatura, which he presents in Il Cortegiano: it is the desirable effortlessness of the courtly persona. It involves a measure of graceful dissimulation: such a one would not reveal his hand too much. An art lay in concealing his very art. Now because this concept reflected and established a whole behavioural ethos in the Renaissance and post-Renaissance

12 Brathwaite 1630, I.

13 Lipsius 1592, sig. $\mathrm{C}_{3}{ }^{\mathrm{r}}$.

14 See Faret 1630, p. 168: 'la souplesse est l'un des souverains precepts de nostre Art'. Castiglione 1561 , sigs. nii ${ }^{\mathrm{v}}$-niii ${ }^{\mathrm{r}}$ places an equivalent emphasis on being 'pliable' in one's relations with others. Kelso 1929, p. 85 sees the Italian ideal represented by Castiglione as one in which the 'graces and not the business of life are insisted upon', in contrast, she says, with the English model. The distinction is perhaps too crude, for the whole point of the former is the fact that the graces are central to the business of life; nevertheless I find myself in general agreement with the contrast. See also Lee Ustick 1932, pp. 409-441 and Lee Ustick 1932-33, pp. 147-166. 
world, the silence in these texts on this subject is notable. It was not as if men in their position did not have access to such works. The evidence shows rather the reverse: England was flooded with editions of courtesy texts in their originals and in translations. Thomas Hoby's vernacular translation of Castiglione in 1561, for example, ran to three further editions in 1577,1588 and 1603 , while Clerke's Latin rendition of the same work proved even more popular, running to eight: the last one in 1619. It is safe to say that most educated men had read the work, that it was one of the most-discussed texts of the period, a cornerstone of the English renaissance. $^{15}$ In his introduction, the humanist and diplomat, Hoby commented that Englishmen were 'inferiour to well most all other Nations' in regard of manners and behaviour and described the work he was about to translate as a 'storehouse of most necessary implements for the conuersacion, use and training up of mans life with Courtly demeaners'. ${ }^{16}$ There were also translations available of Stefano Guazzo's The civile conuersation, Eustache De Refuge's A Treatise of the Court, and Nicolas Faret's The Honest Man or the Art to please in Court. And we know that some of these books were used in Cambridge where both Peacham and Brathwaite had studied. It is next to impossible that they would not have read at least some of them. ${ }^{17}$

When motifs like this are common currency, conventions indeed in a particular genre, the fact of not having recourse to them is highly significant. It suggests that they have set store by a prior value and cannot accommodate this one without in some way denying the first. The seriousness of their stated views on simplicity in the Englishman may well have caused them to believe that grace, sprezzatura and nonchalance, as they were understood, would detract from his plain, upright nature as manifested in honest speech and behaviour. The kind of grace which would carry one through every social situation could be morally quite slippery. The artifice written into Castiglione, no matter how concealed, was still highly contrived: he must 'speak such things after a sort, yt it maye appeare that they are not rehearsed to that ende. ${ }^{18}$ Although neither Castiglione nor any of the continental courtesy writers eschew honesty as such, it is a concept

\footnotetext{
15 It was a popular text in the college libraries of Cambridge - indeed the largest known network of readers were from St John's College. Burke 1995, p. 151.

16 Castiglione 1561, Aiiiir-Aiii ${ }^{\mathrm{r}}$.

17 Guazzo 1586, De Refuge 1622 and Faret 1632. For information on the presence of some of these in Cambridge, see MS 48 (I.2.27) Emmanuel College, Library, Cambridge.

18 Castiglione 1561 , sig. Div
} 
that is inevitably tempered by being constantly integrated in courtly and civil contexts. There is a lot more to honesty than simple honesty: it is eminently negotiable. Peacham and Brathwaite's gentlemen are not especially comfortable fits in the court environment. It is not that they present an ungracious model of speech and behaviour; but there is simply nothing approaching the cult of grace or style that informs other writings in a similar genre. It would seem that they were conscious of not emulating European pedagogy in this regard: the plain style prohibited it.

So the value of plainness was held to be genuinely compatible with true civility and far from being confined to the uneducated Englishmen, prominent writers wished to see it reinvigorated among the country's elite. If not, the country would become decadent. Three sources from the late Elizabethan period successfully dramatise the perceived decline in plainness of speech and behaviour. The result is a textual cluster with more than an element of a morality play about it. That the writers followed markedly different careers only adds to the interest. Francis Thynne was a respectable antiquarian; Robert Greene, the rather disreputable university-educated prose-writer and playwright; Barnabe Rich, a soldier stationed in Ireland for much of his career. The three of them were obviously lively witnesses of the contemporary scene. Thynne's choice of allegory must have struck a chord with the others. The discourse started with the antiquarian's seemingly unpublished poem entitled The Debate betweene Pride and Lowlines in 1570. The text was found, transformed into a prose-drama, and popularised by Greene in A Quip for an Vpstart Courtier some twenty years later. ${ }^{19}$ Immensely appealing, Greene's work went through six editions alone in the year of its publication, a fact that his biographer calls 'astonishing'. Subsequently, the last of the trio thought he would capitalise on this lively market when he took up from where the other had left off, calling the finished burlesque Greenes newes both from heauen and hell. ${ }^{20}$ The three texts memorably present the conflict between an upstart Italianate figure called Velvet Breeches, newly arrived

19 There is some uncertainty about the authorship and the dating of The Debate. The ESTC has it that it is erroneously attributed to Francis Thynne. It also suggests a dating of 1577. I have adhered instead to the view of John Payne Collier who in the 1841 edition of the work, positions it somewhat earlier, claiming that it was written in 1568 , and printed in 1570, although never subsequently published. Thynne 1841, vii-xv. In what Payne Collier has called a 'barefaced piece of plagiarism', Greene 1592 lifted the story from Thynne's work without acknowledgment. Thynne 1841, vi. He makes no reference at all to Thynne, who was still alive.

20 ODNB sub Greene. R[ich] 1593. Greene had recently died. 
in England to demand rights that he clearly does not possess, and the homely defender of traditional values, Cloth Breeches.

The treatment of fashion will be considered at a later point. Language is another layer, and indeed an intrinsic one in the rich texture of attributes that distinguish Cloth from Velvet Breeches, and thus true from false Englishness. ${ }^{21}$ We must remember that there is much resting on the result of this conflict. The question is who has the right to the land? Language is the means by which they make their cases. Cloth is described as somebody who is 'as breefe as hee was proud' and his subsequent speeches, always to the point, even to the point of brusqueness, confirm it. Unlike his opponent, his claim is based on raw honesty: he boasts that he has no 'glosing phrase to trick out my speeches withal'. ${ }^{22}$ It is as if he has nothing else to argue for him except that he is an historic man of his nation and speaks as such: 'let me as I was wont liue famous in my native home England, where I was borne and bred, yea and bearded Caesar thy Countryman'. ${ }^{23}$ Thynne presents a reserved Cloth Breeches who deliberates before speaking in response to his opponent, something that fits his role as defendant rather than aggressor. ${ }^{24}$ His reticence is linked in the depiction to his moral selfrestraint: he responds 'mildly' to one of Velvet's long boastful tirades. Rich's subsequent portrayal shows him tellingly biting his lip as the other vents his spleen on him. ${ }^{25}$ Thus plainness is not conceived as boorish taciturnity but reasonable reserve and necessary speech. To be a plain speaker is to stand up for one's rights, for oneself and for one's nation. It is thus a politically fitting choice for an Englishman. He stands on and for his land.

In the most extensive version of the tale, Greene's Quip, plain speech is particularly correlated with moral agency. This occurs gradually as Cloth becomes increasingly outspoken, even taking it upon himself to dismiss people from the proposed jury, thus usurping what ought to be the narrator's role. The latter is taken aback; he 'wondred and laughte to heare Cloth-breeches make this discourse' and he describes such behaviour as 'peremptory', but does not intervene. ${ }^{26}$ The defendant has become judge. Greene had already challenged his 'gentlemen readers' in the dedication of the work by confronting them with the image of the solemn Cloth,

\footnotetext{
21 Some of the complexities of these texts will be teased out later. See below pp. $81-82$, 86, 89-92.

22 Greene $1592 \mathrm{a}$, sig. $\mathrm{B}^{\mathrm{r}}$.

23 Greene $1592 \mathrm{a}$, sig. $\mathrm{B}^{\mathrm{v}}$.

24 Thynne 1841, p. 11. The other at these woordes was not afeard,/ Ne chaunged collour ne yet countenaunce/ And at the last [...] answeard.

25 Greene 1592a, sig. B3 ${ }^{\mathrm{v}}$; R[ich] 1593, sig. Biir ${ }^{\mathrm{r}}$.

26 Greene 1592a, sigs. $\mathrm{D}_{2}^{\mathrm{v}}, \mathrm{E}_{3}{ }^{\mathrm{r}}, \mathrm{F}_{2}{ }^{\mathrm{r}}$.
} 
leaning on his pike staffe, till he heere what you conceaue of him for being so peremptorie'. He awaits the definitive judgement of readers because, although his fate in the text is well accounted for, his actual fate is in their hands. Would the English gentlemen be on his side? Or would they support the false pretensions and pretentiousness of the other character?27

Two things will have become apparent by now. First, the identification of plain words with the true Englishman has nothing to do with a defence of rustic boorishness and clumsiness of utterance: that kind of speech and behaviour was often satirised, and it certainly awoke no particular chord of recognition, still less of approval in those writers whose work is under review. A 1628 source, for example, dismisses the country fellow who 'speakes Gee and Ree better than English'. So the agenda to restore plainness was not a regressive desire to become like churls. It was rather a moral crusade, to achieve a middle way between extremes in modes of speech. ${ }^{28}$ Second, plain-speakers were invariably envisaged as men. The quality was heavily gendered. One might argue that this is a default position but there seems to be something more self-consciously masculine than usual about the trope. It relies invariably on the presupposition that men were innately direct and women were, by contrast, chatterers. ${ }^{29}$ There was, moreover, a thesis gaining strength in this period that the origins of the vernacular made English a more masculine language than others. The choice of which inheritance to recall is always revealing and in this case, there was a strong strand of thought that, in privileging its AngloSaxon roots and playing down the influence of the Romance languages, brought out and developed its masculine connotations. ${ }^{30}$ For James Howell writing in the 1640 s, it came naturally to make a point of saying that English, being one of the Germanic languages was a full mouthed masculine speech', because taking 'an Englishman Capa pea, from head to

27 Greene $1592 \mathrm{a}$, sigs. $\mathrm{A}_{4}{ }^{\mathrm{r}}-\mathrm{A}_{4} \mathrm{v}$.

28 [Earle] 1628, sig. F $4^{\mathrm{r}}$. Rich 1606 , fos. $4^{\mathrm{v}}-5^{\mathrm{r}}$ has no time for the 'boisterous couersation' of those who 'smell of the Plow and the Cart'. See also Stephens 1615, pp. 251-257 for character sketch of the churl.

29 A particularly incisive expression of this is to be found in Stubbes 1595, p. 57. Hull c1982 treats of this theme with general application to early-modern England.

30 The English defence of Teutonism took life from the work continental philologists of the sixteenth century. See Jones 1953, pp. 214-218. For the most extreme Saxonist perspective on the language see Verstegan 1605; Carew 1904, pp. 285-294 was more moderate, but nevertheless on the same spectrum. It is difficult to say how much these theoretical accounts filtered through into more quotidian reflections on contemporary speech, but they do constitute an important backdrop to thinking on this subject. 
foot every member hee hath is Dutch'. Although he has no ill-feeling against French, saying that it has embellished English over the years, he still considers it to be more fundamental to stress the Teutonic roots of the Englishman's speech because of what it said about their robust manliness. ${ }^{31}$

\section{Politicisation of the Plain ENGlishman}

The plain-talking Englishman was not merely the epitome of unity, morality and masculinity; he could also be a powerful agent in political debate. This complements a recent thesis that there was such a thing as a postReformation public sphere in which new ways of 'political manoeuvre and public politics' were developed. ${ }^{32}$ Whether or not this was a public sphere by later standards does not concern me here. All I would argue is that it became easier and therefore more common to articulate one's views in print and that this new facility transformed the ways in which polemicists argued, the language in which 'demotic' politics was done. In this sense, it may be argued that plainness became the chief rhetorical trope of the man with a national grievance, determined to put his case before a wider public. As such, it was an exceptionally important part of the print polemic of this period and outstandingly so at both ends of the chronological spectrum, that is to say during one of the high points of Elizabethan controversy involving the prospect of a French marriage, and secondly, in the Leveller literature of the 1640 s. Both moments have this in common: that a full development of this line of thinking occurs in relation to the figure of the bluff Englishman. His politicisation may be linked with contemporary discussions of free speech-David Colclough's thesis about parrhesia is of relevance here - and indeed moral freedom more generally. ${ }^{33}$

The prominent Elizabethan puritan writer, John Stubbes, took issue with the proposed royal marriage to the unpopular Duc d'Anjou in 1579 and made strategic use of the figure of common man to argue his case.

${ }^{31}$ Howell 1642, pp. 155-158. Howell indeed just returned from France, and published his first book in his own translation while there. Howell 1640, Dendrologia: Dodona's Grove, or, The Vocall Forest appeared in Paris the following year as Dendrologie ou la forest de Dodone.

32 Lake and Pincus 2007, p. 3.

33 Colclough has conducted a full investigation into the usages of the classical rhetorical figure of parrhesia in secular and religious contexts in early modern England. See in particular his study of early Stuart Parliaments. Colclough 2005, pp. 120-95. He does not treat of the subject in relation to reflections on what it was to be English, however. 
This would be interesting even if, as was once generally thought, he had been asked by powerful councillors, the Earl of Leicester and Sir Francis Walsingham, to engineer a popular case for the issue. It is even more interesting now because, according to Nathalie Mears' close study of the text, this is not a piece of commissioned propaganda but an independent attempt to lobby Elizabeth, and as such, indicative of a new culture of counsel and public debate. ${ }^{34}$ His claims in The Discouerie of a Gaping Gvlf wherein England is like to be swallowed to be 'of the meaner sort' were somewhat disingenuous, given his own education and stature. ${ }^{35}$ Nevertheless, the pretension of plainness is a potent weapon that he uses to argue that it would be nothing short of disaster if Elizabeth married this French Papist. Anjou was the fifth son of Henry II and Catherine de Medici and although diplomatically this may have been a good match, impediments of nationality, religion and age (she was 46 to his 24) were put forward against it. Stubbes shuffles off the authorial voice, and puts the definitive judgment into the mouth of this plain sooth-sayer: 'well may the simple Englishman say, timeo gallos, namely Valesios [the Valois], nuptias ambientes especiallye such mixt marriages'. ${ }^{36}$ Of course, such an Englishman would probably not have enough Latin to say as much as this, or any knowledge of the Virgilian origins of the phrase which explains its resonance, but as Colclough notes in this regard, '[f]rank speech can be ornate as the speaker wishes to make it'. ${ }^{37}$ What is important is that at this sensitive juncture when the fate of the land is in the balance and when more sophisticated people have gone astray, this decidedly homely figure, unrestricted in what he may say by the requirements of diplomacy, and unrestricted in what he does say by any particular finesse appears to be the only one to speak out with the voice of sound common-sense, urging withdrawal.

Those who supported and encouraged the match were, by contrast, 'halfe taughte Christians and halfe harted Englishmen' using 'smooth wordes'. Not being 'playne dealing' in themselves, the deal that they were pressing upon the Queen and the people was bound to be a

\footnotetext{
34 Mears 2001, pp. 629-650.

35 [Stubbes] 1579, sig. E2 ${ }^{r}$. Stubbes had matriculated at Trinity College, Cambridge in 1555, and had then proceeded to Lincoln's Inns, where he was called to the bar in 1572. He was also related, through his sister's marriage in 1578 to Thomas Cartwright, the Cambridge divine, although that was hardly a point likely to work in his favour with the authorities by then.

${ }^{36}$ [Stubbes] 1579, sig. C3 ${ }^{\text {v }}$. Timeo Danaos et dona ferentes. Virgil Aeneid, II, 49.

37 Colclough 2005, p. 19.
} 
harmful one. ${ }^{38}$ Thus, to be plainly-spoken was to be loyal and true; to be given to persuasive rhetoric on this matter was to be degenerate because one was trying to bring about a situation in which Englishmen would ultimately be put in the power of the Pope through French intermediaries. He proceeded to urge the Queen to 'make much of playne honest speakers, and to put out of hart al flatterers' but even such conventional humanist wisdom, expressed repeatedly throughout the mirror-for-princes literature, derives more particular meaning from the context; the true Englishman, as he styled himself to be, would speak what he thought, regardless of royal reaction and thus indeed it proved. Stubbes was punished by having his right hand amputated, and his declaration that, as a 'true Englishman', his were not the words of a 'busie body, speaking at all aduentures' came to haunt him. ${ }^{39}$ Not only was he a 'religious parrhesiast', as Colclough calls him, he was also a self-consciously English parrhesiast, one who justified boldness of speech in terms of national authenticity. His case and his way of making the case are one. ${ }^{40}$ His lines were neither fine nor original, but he earned a hearing. And that was the whole point. It was the simple spontaneity of his utterances that gave them value as counsel. Is he is as plain a speaker as he claims? Hardly. The very faux-simplicity is sophisticated. There was nothing more sophisticated than the attempt to 'mobilise various publics' to prevent the Queen 'from doing things she wanted to do.'41

If Stubbes was foremost in Elizabethan times in politicising plainness of utterance in the national cause, at another time of major stress, namely the Civil War period, there is a more extensive and incisive manifestation of the same outlook, in the voluminous pamphlet literature of the amorphous grouping known as the Levellers. ${ }^{42}$ This group were outside the established and even the main revolutionary circles of power: plainness became their justification for an entrée into politics. Their polemic was written to make its point quickly and emphatically: there was no time for elaboration. The towering persona that John Lilburne creates for himself in his pamphlets is that of the plainly-spoken Englishman

38 [Stubbes] 1579, sig. B6v . Presumably the Englishness of those clergy who were studying more for 'smooth delicate wordes then for playn rough truth' was only half-hearted too.

39 [Stubbes] 1579, sigs. B $7^{\mathrm{r}}, \mathrm{F}_{3}^{\mathrm{v}}$. I shall treat of this text as regards its anti-Catholicism at a later point. See below pp. 137-143.

40 Colclough 2005, p. 91.

41 Lake and Pincus 2007, p. 3.

42 I shall deal more extensively with the properly political dimensions of Leveller thought. See below pp. 227-252. 
constantly repeating the same home truths, however unpalatable to those in authority - and at various stages, they would have been unpalatable to very different sorts of authority as the country went through its many transformations. He was a leveller fighting against social privilege and an Independent colliding with the Presbyterians. Amidst all the corruption he claimed to find in high places, he was the 'faithfull plaine dealer', his account the 'bare, naked, and single' one of an Englishman, those on whose behalf he spoke the 'honest plaine-hearted men of England', and that which he opposed the 'subtill practices' of his opponents. ${ }^{43}$ Even the rough style of his pamphlets confirm the nature of his selfproclamation: written with the immediacy of direct speech and with the same unrehearsed quality, he fixes on the most basic of rhetorical units which, repeated usque ad nauseam, strike home forcefully despite his otherwise rather convoluted syntax. Needless to say, he has no use for classical allusions, although he would have had a grammar - school knowledge of them. In short, although a writer, he seems to be more of a speaker: there is something of the whine of the thwarted demagogue clinging to all his prose. He had other voices to back him up in his espousal of plainness. William Walwyn, who had first met him in 1645 and became a devotee of similar causes, affirmed in his Englands Lamentable Slavery that the 'honest and plaine men of England' would be Lilburne's true judges and would speak on his behalf, just as he was speaking on theirs. ${ }^{44}$ Walwyn wrote from this personal perspective also, as one drawn from the trustworthy ranks of the 'plain-hearted people in England'. ${ }^{45}$

What were these polemicists were trying to do by such an appeal to and personal espousal of plainness? In the first place, it functioned as a high claim to righteousness: every claim to truth, as Kenneth Graham has observed, is 'likely to call itself plain at some point' and this is what we see happening with the dogged insistence that characterises them. ${ }^{46}$ Yet, far from being merely a lofty boast, it was also highly tactical primarily because it placed agitator and audience within the same bracket. The former were

43 Lilburne [26 July] 1647, p. 10; Lilburne, Prince and Overton [11 April] 1649, p. 4; Lilburne [6 October] 1649, sig. Avv; I. L. 1647, p. 3. The ESTC holds that this latter pamphlet entitled Plaine Truth Without Feare or flattery is erroneously attributed to Lilburne and attributes it instead to Amon Wilbee. I have simply listed it under the given initials in the bibliography and make no judgement as to its actual attribution.

44 Walwyn [October] 1645 in McMichael and Taft, p. 151.

45 Walwyn [June-July?] 1649 in McMichael and Taft, p. 421. The other particulars of his vision of Englishness will be considered at later. See below pp. 239-240, 243.

46 Graham 1994, p. 2. 
pre-empting accusations that they may have been exploiting the campaign of liberty for merely personal ends by stressing instead that their whole aim was to be of use to their fellow countrymen. Thus they alone said how things really were, rather than how the authorities said they were. This is the logic behind the appeals to have the laws put into plain English. Only when they were shorn of French could they be accessible to a nation of plain-speakers. ${ }^{47}$ Who was plain-dealing in the 1640 ? ?heir answer is that the common Englishman alone is right-thinking and that they are his representatives. There is perhaps something a little suspect to us about the smugness behind such self-presentation, yet it is not entirely complacent. Plainness had its concomitant disadvantages: to describe the people in such a way was to point to a strength which was also a vulnerability. Simple Englishmen were capable, as Lilburne constantly made clear, of being deluded and even destroyed: one of his reasons for printing his thoughts in 1647 was to thwart Oliver Cromwell's efforts to deceive 'honest simple hearted plain dealing men'. ${ }^{48}$ The new men of government were betraying the great national cause. It would also seem, by insisting on this value, that they were grooming themselves more for exercising moral pressure than political power: to lay claim to guilelessness was, in fact, to imply a principled aloofness from the murky dealings of the decade, whether courtly or parliamentary and as such, was the language of men without power, except that of their word as critics and their experience as victims. Plainness was all that they possessed.

\section{The SPeEch of Returned Travellers}

The plain-talking Englishman was no less of an ideal, albeit a more implicit one, in the condemnation of the two characters deemed excessive in their speech forms, namely the homecoming traveller and the courtier. These categories were not in the least mutually exclusive: on the contrary, courtiers accounted for much of the travel undertaken by Englishmen in the period. The distinction is not necessarily one of person then, but more one of emphasis: the traveller is associated more with direct loan-words, strange pronunciation and chatter; whereas the courtier attracts criticism

47 Upon this point see Lilburne [14 February] 1648, sig. a3v; Lilburne [10 August] 1649, p. 48. We recall how lawyers' English had been satirised by Wilson 1553 , fos. $86^{\mathrm{r}}-86^{\mathrm{v}}$.

48 Lilburne [26 July] 1647, p. 10. This incidentally was penned just months before Cromwell gave the movement the name by which it has become known to history. 
in a wider way for engaging too much with an exotic language of compliment. Yet the lines of thought dovetail at every stage: in short both types of men were accused of taking an à la carte approach to English ways of saying and doing things. They were harshly presented as agents in others' degeneration as well as their own, clearly more sinning than sinned against.

The problematisation of the first figure occurs against the backdrop of a vogue for continental travel, which by the late sixteenth century was becoming a more staple feature of the elite Englishman's education. A recent historian has pinpointed the origins of this trend in Edward's short reign. ${ }^{49}$ Classically, the logic of this sort of travel was pedagogical. It was meant to give one a grounding in the world of antiquity and a fine understanding of contemporary affairs. Thus it had a civic purpose: the idea was that one would return in a better position to serve the commonwealth, putting the knowledge and expertise acquired when abroad to advantage at home. In practice, however, it was often thought more likely that the traveller had undergone or would undergo religious, moral, or political corruption when away, forsaking the essence of his being for false manners and habits. It was in the light of these dire eventualities that a literature of imperatives and cautions sprung up around him..$^{50}$

In the burgeoning neo-Theophrastan character literature of the early seventeenth century, it is not surprising to find the frailty of the type concisely drawn in the context of concerns about how he had let his national identity slip. The character sketch, in the manner of Theophrastus' On Moral Characters, was a popular genre in an age which delighted in prodding the humours and vanities of men in high places. It is trenchant comedy with a serious vein. John Stephens' 'Ubiquitary' in his Essayes and Characters is a good example. ${ }^{51}$ Stephens was one of the many satirists

49 Brennan 2004. It was not until the end of the seventeenth century that this kind of travel became something of a compulsory rite of passage. It is difficult to get an idea of the exact number of young men who went abroad for purposes other than commercial: diaries, travel itineraries, and guides as well as a large number of incidental references would indicate that it was not negligible, and apparently sizeable enough to warrant concerns about reintegration on return.

50 That there was also a significant literature by travellers as well as about them is something not to lose sight of, although it proves to be less revealing for us. Well-known accounts include Coryate [1611] and Moryson 1617. Stoye $195^{2}$ and Brennan 2004 provide an analysis of this and other material.

51 For fuller treatment of the Theophrastan literature in English from 1592 to 1642 , the era in which it reached full growth, see Boyce 1976. For details of sixteenth- and seventeenth-century editions, including the first English edition of 1616 see particularly Boyce 1976, pp. 177-178. See also Greenough 1947. 
who congregated around the capital, professionally involved in law but now and then compiling his store of observations into published form. What he objected to was the kaleidoscopic identities that the traveller presented: 'euery houre, almost, giues him a new Being, or at least, the purpose to bee an other thing then hee is'. The particular culprits are singled out: 'in his behauiour he would seeme French, Italian, Spanish, or anything'. ${ }^{52}$ His worry is ontological: what constitutes his being if it is so will-o-the-wisp?

Another point made is that the traveller can never truly be a free Englishman. Brathwaite's depiction of the Journeyman in his 1631 Whimzies: or a nevv cast of characters is in a somewhat similar vein to Stephens', except that it is more politicised. The travelling Englishman 'can never bee a freeman, till hee bee endenized in his owne Countrey.' True liberty is only to be found at home. He satirises the traveller's itch to go abroad, saying that he is 'troubled with a perpetuall migrim'. The resonance of this figure of the freeman, increasingly to the fore since the parliamentary debates of 1628 , gives this comment a very particular edge. It was as if the journeyman was disabled from all the privileges consequent on his national status, as if the liberties confirmed by the Petition of Right were set at nought in his regard. Even when such a one was cured of his 'migrim', his status is questionable because he would have 'mould[ed] himself to all conditions, fashions and religions' while away. ${ }^{53} \mathrm{He}$ does not push this point further; it was for others to draw out this connection between imitation and slavery.

The issues will be further thrown into relief by considering James Howell's Instructions for forreine travel, a manual setting out precepts useful to the Englishman before, during and after the three years or so that he would spend abroad. ${ }^{54}$ Hale's comments are of particular interest because he was not a crabbed traditionalist but a well-travelled man himself, who approved of the practice but with cautions. Indeed, he devotes two sections to the traveller's return and is emphatic about first principles: he who 'savoureth of no affectation; or Strangenesse, of no exotique modes at

\footnotetext{
52 Stephens 1615 , pp. 233-4.

53 [Brathwaite] 1631b, pp. 147, 150. See below pp. $213^{-225}$ for discussion of the selfconsciously English tone of the debates of 1628 .

54 Howell 1642, p. 14. He estimates three years and four months will suffice for crossing France, Spain, Italy, observing 'the multiplicity of Governments therein'; and also for climbing the Alps, traversing the best part of Germany, and the 'Belgique Lion', p. 174. He was in prison when he wrote this, although it is unclear whether for debt or royalist activities.
} 
all, after his returne, either in his Cariage or Discours' is the most discrete traveller, the truest Englishman by another reckoning. He underlines the importance of remaining English at heart. ${ }^{55}$ It is interesting to note en passant that Howell's own Welshness does not seem to impinge at all. Whatever the traveller has gleaned of foreign ways, and Howell does permit him to acquire some of them for specific ends, he must now 'abhorre' all 'affectations, all forced postures and complements'. He deplores how many of his contemporaries 'wander from themselves' and return 'mere Mimiques' ${ }^{56}$ The necessity of returning home to oneself and not just one's country is a good example of the embryonic language about national being that we noted in Stephens. Perhaps referring to the ontological content of such views does makes their ideas out to be more theoretical than they are in reality; still, there are intimations. This, in any case, is how they talk about identity. Most worryingly of all for Howell was the fact that travellers were not passive floaters in this process; rather did they themselves 'strive to degenerate as much as they can from Englishmen', flouting their own natures, as it were, in a wholly reprehensible way. ${ }^{57}$

The main principles and concerns about the traveller having thus been established, the question of speech needs to be examined, because language 'the greatest outward testimony of Trauell', as Howell had put it, could also be the most offensively evident when exotic modes infiltrated such a one's everyday conversation. ${ }^{58}$ The penchant for mixing languages received its most thorough condemnation from Wilson, who, as has been seen, kept a weather eye on the contemporary scene even as he traced the more formal aspects of rhetoric in The Arte. The outstanding issue for him was the propensity of 'farre iourneid ientlemen' to return speaking 'French English' without blushing and chop up their native tongue with 'Angleso Italiano'. Be it added that the Inglese Italiano had long been a figure of hate in popular culture. A case could be made against them for actually

55 Howell 1642, Sect XIV and XV, pp. 173-195, 191, 190. 'His heart must still remain English'.

56 Howell 1642, p. 174.

57 Howell 1642, pp. 174-5. A much more pragmatic source is Robert Dallington's $A$ method for trauell [1605?]. He states early on that he who wants to travel must move 'out of his country fashion, and indeed out of himselfe' - by this he is referring to the youthful habits of over-drinking, gambling and violent exercise. On return however, he should come out of all foreign 'humors and habits', and instead 'come home to himselfe, fashioned to such a carriage in his apparrell, gesture and conversation, as in his owne country is most plausible'. (sigs. $\mathrm{Br}^{\mathrm{r}}, \mathrm{Cl}^{\mathrm{v}}$.) The key word here is plausible: it shows that his thinking his guided by pragmatism. He is not seriously interested in considerations of an English nature or heart.

58 Howell 1642, p. 196. 
'counterfeitying the kynges English' 59 The image invites us to link hollow language and false coinage: neither rings true. Of interest also is the reference to the monarch in legitimating the standard language. As established earlier, Wilson was of the opinion that there ought to be no dividing line between elite and common English. Both ought to be fundamentally alike, the authority of royalty guarding the clarity of the other. It is rather the middle ranks, the lawyers, auditors, fine courtiers, savants and these traveller types that are obscuring truly national modes of utterance. ${ }^{60}$

Wilson uses another striking image in reference to the English traveller's speech that has much in common with the idea of counterfeiting, that of cosmetics. He accuses them of 'pouder[ing] their talke with oversea language'. If powder concealed blemishes and enhanced feature, the question is why should the Englishman need it? Their language was sufficient without it: they were sufficient without it. He is evidently discomfited by the effeminacy of this practice, a discomfort made more apparent by the subsequent disparagement of the new penchant for 'forrein apparel', a nudge to the effect that men were becoming too womanish by showing excessive interest in the latest fashion. ${ }^{61}$ But there is one other implication to be teased out in regard of his mordant comments on the traveller. It involves an ambiguity in respect of where he locates superficiality. It is an open question as to whether it rests with the imitative Englishman himself or is inherent in the foreign codes. If the first, then he alone is to blame in bringing back the most trivial of baggage, ignoring what may be of real value in other cultures. If the second, then he may want to suggest that 'oversea language' and its speakers had more than their fair share of rhetorical affectation, and that they could only export what they possessed. This ambiguity is in keeping with his general ambiguity with regard to Italy in particular.

Where Wilson pursed his lips, the more demotic Barnabe Rich raged. He was one of the more determined 'Satyrists and Critickes of these times' and certainly one of the most voluble, writing half a million words. In a socially purgative work entitled Faultes faults, and nothing else but faultes, he rounded on the hapless traveller, whom he described as returning 'full

59 Wilson 1553 , fo. $86^{\mathrm{r}}$.

60 Wilson 1553 , fos. $86^{\mathrm{r}}-86^{\mathrm{v}}$.

61 Wilson 1553, fo. 86 . Cathy Shrank pinpoints both issues when she observes that these 'French-talking Englishmen and 'Angleschi Italiani' - Englishmen grotesquely mutating into Italians - display a tongue as un-English and effeminate ('pouder[ed]' like women's faces) as their exotic garb'. Shrank 2004, p. 191. 
fraught with farre fetcht follies'. He ridiculed it as one of the whipsters' 'outlandish vanities' the practice of adding 'some foolish phrases' in French, Spanish and Italian to English speech. Rich is making the most of both literal and metaphorical connotations of the word outlandish: only since the 1580 s had it acquired the pejorative meaning of strangeness in the sense of outrage, having originally being a neutral means of designating things foreign. Again, it is an open question at this point whether he was saying that the outlandish was foolish in itself because it was foreign, or just inappropriate when transposed: both interpretations are viable and perhaps, indeed, intended. He pressed home the seriousness of the issue by remarking that these kinds of practices made them untrustworthy at home. They lose their 'credite at home'. In a society obsessed with reading honesty, such a destruction of social trust was a grave issue. ${ }^{62}$

Beneath the dislike of linguistic bric-à-brac may be discerned a preference for integrity, which Thomas Dekker's ironic injunction to courtiertravellers to 'publish your Languages, if you haue them; if not, get some fragments of French or small parcels of Italian to fling about the table' illustrates well. ${ }^{63}$ In Howell, a much more self-consciously authoritative voice, one seizes upon this more fully: a central feature of the homecomers' attempt to continue the process of degeneration was that 'all their talke is still Forraine'. ${ }^{64}$ Their mind is still residing elsewhere. Abandoning one's mother tongue is symbolic of abandoning the fatherland at least in spirit, even when bodily present as they are. For a practice that was motivated by a combination of playfulness and ostentation on the part of the self-conscious cosmopolite to have attracted this sort of attention is a clear sign of how deeply it could cut into an evolving sense of the national self.

Such a Babel-like mingling of tongues was compounded by the tendency on the part of this ambiguous creature to pronounce English words themselves in the manner of a foreigner. In his Pierce Penilesse his supplication to the diuell, Thomas Nashe revelled in some sharp satire at the expense of London types, among them, 'a dapper Iacke, that hath been but

62 Rich 1606 , fos. $2^{\text {r }}, 8^{\text {r }}$.

63 Dekker 16og, p. 23.

64 Howell 1642, p. 175. The issue of mixing did not die out. The author of Remarques on the humours and conversations of the town was even willing to concede adoption of French fashions, as long as the languages are kept from mixing: 'better to let them [the French] command our dresses, than our Language'. It is not that he is hostile to French per se indeed he sees it as necessary for court life and world affairs, but he is adamant that there should be no 'mix'. S.L. 1673, pp. 98, 101. 
ouer at Deepe' who had returned talking 'English through the teeth like Iaque Scabd-hams or Monsieur Mingo de Moustrap'. It seems to have formed part of a general perception that the Frenchman 'mangleth, cuts off and eates many letters'. But here, it is weighted with particular venom because it has found its way into an Englishman's speech. By stifling his natural accent, plain (albeit aspiring) Jack had become a French Iaque, a would-be aristocrat, the ridiculousness of his formal designations revealing all the keenness of satiric intent. In the next breadth, unsurprisingly, Nash dismisses him as 'poor slaue'. A propos the change in names, it is of relevance to note that William Camden, in his discussion of Christian names several years later, would depart from dispassionate commentary to snarl against the gallic version of James, 'which some frenchified English, to their disgrace, have too much affected'. Nashe's eye for the telling detail was one of the reasons why Pierce was one of his most popular works: according to his biographer, its worldly gossipy tone caught 'the intellectual pulse of the 1590s'.65 Sir William Cornwallis, an essayist inspired by Michel de Montaigne, observed that people will 'tell you where they were last, by their behaviour, and table-talke, as well upon the inwardest acquaintance', noting in particular that a year in Italy seemed to make people forget their English and 'speake it broken'. ${ }^{66}$

So far the point has been that speaking English strangely made one a stranger too, but that there is more to the matter is evidenced by the fact that speaking English without articulating properly was seen by some as symptomatic of a whole attitude of dissatisfaction with and disparagement of one's own. ${ }^{67}$ To an extent, this is to be inferred from the above image of a truculent Iaque speaking through clenched teeth, but it is made much more explicit in the depiction of the traveller by Thomas Overbury, who, writing like Stephens in the Theophrastan mode, noted that such a one now 'speaks his owne language with shame and lisping,' thus allying the loss of pride in his mother tongue with the loss of competence in speaking it properly. ${ }^{68}$

Lisping had a long and controversial provenance in England. Mentioned by Chaucer, it seems subsequently to have been associated with the French

65 Nashe 1592a, sig. B2 ${ }^{\text {r }}$; Howell 1642, p. 73; Camden 1605, p. 59; ODNB. Pierce went through 5 editions in 3 years.

66 Cornwallis $1600-$ sigs. $\mathrm{L}^{\mathrm{v}}-\mathrm{M}^{\mathrm{r}}$.

67 An interesting interpretation of the traveller-malcontent and the nature of his melancholy with particular reference to Jacques in Shakespeare's As You Like It is to be found in Fink 1935, pp. 235-252.

68 Overbury 1616 , sig. D1 ${ }^{\mathrm{r}}$. 
fashion for 'parler gras' (soft speaking) in the sixteenth century, so John Stubbes' claim to recognise a Frenchman by 'his hissing and lisping' is nothing uncommon. In this case, it was the Duc d'Anjou who is the particular target, and it was linked with his Catholicism and his daily attendance at Mass - a typical Protestant accusation against Catholics mumbling their prayers inaudibly in church. Later in the same work, he snipes at 'euery lisping vvord and crouching curtesie of a French Ambassador'. ${ }^{69}$ Importantly, Randle Cotgrave writing his bilingual dictionary defined 'parler gras' as a 'lisping, or not pronouncing of R', so it was not necessarily or even principally used to denote the replacement of sibilants with interdental sounds in the period. ${ }^{70}$ An occasional indiscriminateness as to attribution - for Cornwallis it was a year in Italy that made the man 'forget his English, and speake it broken, and lisping' - may indicate that the practice incorporated any way of speaking particularly disliked and felt to be too soft. ${ }^{71}$ The suggestion of effeminacy and childishness indicated by this defect is unmistakable, both connotations that will figure repeatedly in the construction of the foreign. In Richard Carew's treatise on the Excellency of the English tongue, Italian had been criticised for lacking in 'synewes', French for being 'ouer nice' like a woman 'scarce daring to open her lipps for feare of marring her countenaunce'. Speaking English as if it was either would thus be inappropriate. ${ }^{72}$

There may have been other reasons for this reaction against what was deemed Frenchified utterance. By far the most politically intoned one advanced for the unpleasant 'whining kind of querulous tone' among the French, especially the peasantry, was that proposed by Howell in 1642. For him, it has its roots in the condition of 'pittifull slavery they are brought unto' ${ }^{73}$ In other words, they sounded needy and importunate because their masters were arbitrary and tyrannical. The Englishmen listening to them had fallen 'a lisping and mincing' and in their turn 'distort[ing] and 'strain[ing] their mouths and voice, so that they render themselves fantastique and ridiculous'. Absurdity was one thing, but an even more serious

69 Chaucer's friar had adopted a lisp purely for affected purposes: 'Somewhat he lipsed for his wantownesse, To make his Englissh sweete upon his tonge'. 'General Prologue' to the Cantebury Tales, 264-265. [Stubbes] 1579, sigs. A2 ${ }^{\mathrm{v}}, \mathrm{C6}^{\mathrm{r}}$. For a treatment of the French lisp see Carrington Lancaster 1934, pp. 243-4.

70 Cotgrave 1611, sub gras, sig. Ttiiiij'. He translated 'grassier' as to lisp.

71 Cornwallis $1600-01$, sig. M1 ${ }^{\mathrm{r}}$. Cleveland 1647 , p. 42 notes that the Scots have learned to lisp abroad.

72 Carew 1904, p. 292.

73 Howell 1642 , pp. 27-28. Howell was of the belief that every tongue had a 'tone or tune peculiar to her self'. 
implication was left unsaid: by imitation, had they also rendered themselves slavish? In the crises that marked the year of its publication, such an implication would not have been missed. Perhaps Howell had read his Henry Parker. ${ }^{74}$ In any case, he would have been alive to contemporary concerns surrounding the fate of the Englishman's liberty. What comes across is his powerful conviction that the 'true genuine tone' of the Englishman could not accommodate any ring of the slavish. Plain and free speech was not dependent speech. ${ }^{75}$

Questions of nationality arose not merely from what or how one spoke, but also the extent to which one spoke at all. There are signs, as we have seen in the characterisation of Cloth Breeches for instance, that English plainness entailed what one refrained from saying as well as what one said. Roger Ascham, one time fellow of St John's College, Cambridge and former royal tutor, was particularly preoccupied with this new-found volubility, and he blamed Italy for it. Coming after his depiction of religious and moral decline, he portrayed the English Italianated as 'common discoursers of all matters', believing themselves qualified to air opinions on everything. Far from revering their experience, his words discredit it; excess of speech had no correlation to worth of substance. In acquiring a 'discoursing tong' under the Italian influence, the plain tongue proper to Englishmen was no more. ${ }^{76}$ Ascham presents a particularly interesting instance because he is not altogether averse to courtly models per se but whatever about the courtier coming to meet the Englishman in the safe guise of a translation written by someone who had been at Cambridge he praises Thomas Hoby's translation of Castiglione - there was something more bothering about the Englishman going out to engage with the totality of Italian society and coming back, a mindless chatterer. ${ }^{77}$ Nor was he the only one to bracket together unrestrained and empty verbality with alien influence. Not referring to any one influence in particular, Overbury notes that the traveller's 'discourse sonnds big, but meanes nothing', Rich

${ }^{74}$ Howell 1642 , pp. 27-8. We are unable to establish the exact date of Howell's work, as it does not appear in the Stationer's Register. Parker's Some few observations and his more famous Observations were published anonymously in early and late summer of 1642 respectively. For further comment on Parker see below pp. 273-279. Howell goes on to qualify his position somewhat by saying that the 'French tongue like the Nation, is a bold and hardy speach, therefore the learner must not be bashfull or meale mouth'd in speaking any thing'.

75 Howell 1642, pp. $27-8$.

76 Ascham 1570, fo. $30^{\text {r }}$.

77 Ascham 1570, fo. 20v . Thomas Hoby arrived in Cambridge in 1545; Ascham who had matriculated in 1530 had to leave around then owing to ill-health. ODNB. 
that he will vacuously talk on and on about the magnificence he has seen, hardly pausing for breath, whilst Brathwaite's journeyman 'runnes on in a mere verbal circuit of affected discourse, which the ignorant onely admire, and weaker than women affect'. ${ }^{78}$ The circuitous nature of his talk reveals its complete lack of direction: if not quite thoughtless, what thought there is, is superficial and effeminate, for women, traditionally held to be more roundabout in their social behaviour, were also deemed more diffuse in their speech. The traveller has abandoned the meaning of true communication.

The fundamental reason why the traveller's speech was cause for concern however was not simply linguistic but moral, and if moral, then not merely a private matter but a public one: a national one. The traveller was held to have picked up the vice of hypocrisy as well as languages, a fault particularly associated with the Italian states in the conventional moral geography of the day. In fact, it was seen by many as their innate characteristic. The worst of it was that it could be a vice concealed under a host of courtly virtue. John Stradling who loosely translated Justus Lipsius' Epistola de Peregrinatione Italica into A Direction for Travailers, added in some nationally-specific elements by declaring that 'other nations haue greater facilitie to hide their vices then we English men' and he urged them, in their very frankness, not to be beguiled. English nature is particularly prone to imitating foreign vices and to 'entertain[ing] stranger artificers' being attracted because they are so 'strange', seem so 'delightful' and beguile them with 'glose'. Just as it was part of English nature to be 'free, ingenious and open', Italian hypocrisy, deceit and malice were 'naturall unto them' ${ }^{79}$ The Earl in Nashe's picaresque novel The Vnfortunate Traveller, with all his Italian experience cynically told Jack, the roguish young English page, that lying and prating were the ways to get promotion abroad. Rich says emphatically that the travellers return feeling themselves 'priuileged to lie'. ${ }^{80}$ The guileless English learned the deceitfulness of the Machiavel. Nicholas Breton sighed over the influence of Machiavelli whose 'Rules have metaphormol'de many a minde' and who had destroyed a golden age of 'Plaine meaning'. ${ }^{81}$ Roger Ascham whose attitude to Italy was ever ambiguous judged that, all the while showing off a veneer of civility, a

78 Overbury 1616, sig. D1v ${ }^{\mathrm{v}}$, Rich 1606 , fo $8^{\mathrm{v}}$, [Brathwaite] 1631b, pp. 150-1. The attribution of prating to foreign travel is also visible in Lodge 1596, p. 4.

79 Lipsius (1592). A direction for trauailers, sigs. $\mathrm{C}_{2}{ }^{\mathrm{rv}}, \mathrm{B}_{3}{ }^{\mathrm{r}}$.

80 Nashe 1594, sig. L3v ; Rich 1606, fo. $8^{\mathrm{v}}$.

81 Breton (1602), sigs. Ev $\mathrm{E2}^{\mathrm{r}}$. 
'smiling countenance and much curtesie openlie to all men,' the English Italians were in reality 'open flatterers' and 'ready bakbiters'. Verbally dexterous, with all their arts honed through imitation, they knew how to manipulate language so as to achieve nefarious ends. 'Faire speakers' they may have been, honest Englishmen they were not: that was the measure of their transformation, or rather, degeneration. ${ }^{82}$ Now, when the earlymoderns talk of vice, it is rarely just as it affects private individuals. Vice brought the whole nation into shame: it was a general corruptor. It is not too much to say that the traveller returned, a canker in the body politic.

The traveller is thus a truly borderline figure, one whose engagement with foreign cultures endangered his language and by extension also, the very essence of who he is. Where the 'self' is being construed as an English self, the fact that he does not return to 'himself convincingly is indeed a damning indictment. One detects great discomfort with this man's connivance in his own loss of identity, for it was that capacity to be an agent in one's own transformation and not merely a victim of overpowering external influence that caused critics to fret so much. More deeply lies the sense that he could also be an agent in changing English ways on his return. An uneasy belief that change was afoot in modes of discourse, regardless of what was said or counselled on the matter, was even more profoundly evident in depictions of the courtier and court culture. The court's invariably cosmopolitan character meant that the Englishman did not have to travel to imbibe foreign ways; they were accessible through more immediate channels.

\section{The Courtier's Velvet Terms ${ }^{83}$}

That a caricature of the courtier was very popular is evident enough throughout the period, and that, for the same reasons for which courtiers were traditionally mocked - the reputed deceitfulness of their characters, the shallowness of their code of honour, and their indulged habits of decadence. These are motifs with a history that closely binds them - in the English case - to reflections on national identity. ${ }^{84}$ Courtly ways of using

82 Ascham 1570 , fo. $30^{\mathrm{r}}$. Upon the figure of the despised figure of the Inglese Italianato in general see Warneke 1995, pp. 105-37 and especially pp. 107-08 upon the point of the origins of such a stereotype.

${ }_{83}$ The collocation velvet terms comes from [Dekker et al.] 1603, sig. C1v . See below p. 63 .

84 Smith 1966 in discussing the anti-aulic trend in sixteenth-century France provides some interesting parallels and contrasts to my analysis. There is unfortunately no comprehensive study on the influence of classical thought on early-modern anti-aulic sentiment. 
language came under this cloud of general moral suspicion of this character. The imperatives of what we may call - in a loose sense - the court culture of ancien regime Europe prompted the codification and elaboration of a highly ritualised language of compliment, understood here in its older sense as the observance of ceremony in social relations. ${ }^{85}$ Court-talk was felt to be coloured. It was something less than formal oratory but something more than casual speech. Compliment had two faces, by one token ensuring pleasing and amiable rapports between and within elites, yet, and this invariably lurks uncomfortably in the background of the works of even the most committed of proponents, it did tend to give the upper hand to those who could manipulate language more artfully to bid for favour or promote oneself or one's protégés. It was inherently morally suspect.

There was some justification in questioning the court as a reservoir of English values. It was the location, above all others, where the national and the foreign intermingled. Smuts has studied the Europeanisation of court-culture under the Stuarts; it was also a property of the Tudor court. ${ }^{86}$ Moreover, the fact that some of the most popular manuals of courtly behaviour in the sixteenth century were Italian, and in the seventeenth French, something that alone would have made the courtier a suspect figure in the eyes of many. There was, as Anna Bryson points out, no 'fullscale' English treatise of the court. ${ }^{87}$ The hegemony of the Italian model, classically presented by Baldassare Castiglione in Il libro del cortegiano of 1528 gave way to French empire over the verbal art de plaire in the later period (understandable given the huge growth of the French court), but this was more of a general drift than a rigid rule. As late as 1642, we find Howell still referring to Italy as the 'prime climat of complement'. ${ }^{88}$ By then, the shadow was very long indeed. The powerful Castiglionian model had presented social behaviour and social interaction as a kind of parlour

85 It tends to be spelled as 'complement'. OED sub complement, $8 \mathbf{1}^{\circ}$. Whether we are talking of an emergence of something new or an intensification of medieval trends, it is not possible for me, as an early modern historian, to say. But see Burke 1993, p. 19, who discusses the 'inflation of polite forms' emanating from the Italian courts of the Quincento.

86 Smuts 1987.

87 Bryson 1998, p. 37. Compared to Italy and France, Spain was cited to a lesser extent, perhaps because the Castilian court rituals were so rarefied and inaccessible.

88 On the growth of the French court see Burke 1988, p. 101. Howell 1642, p. 104. Crane 1920 investigates the development of Italian social customs in the sixteenth century; for treatment of the influence of such customs on England see Javitch 1978, pp. 4-5 and Bryson 1998, pp. $75^{-80}$. 
game and the civilised man as an adept at shifting from 'role to role'. ${ }^{89} \mathrm{His}$ speech was of a piece with the sophistication of his persona. Speech ought to be 'faire, witty, subtil, fine and grave according to the matter'; the voice should be 'clere, sweete and wel framed' with 'fitte maners and gestures'. He should be able to discourse on not just serious but 'pleasant maters', 'mery conceits', 'honest divises' and jests. One of the chief Castiglionian imports was a new-style language of courtesy where grace of utterance and manner were privileged over, its critics declared, true meaning and simplicity. It was a language of luxury, of excess, of masking, a language which could say something but mean another. The courtier is, in fact, encouraged to take 'certain woordes in an other significacion then that is proper to them, \& wrasting them to his purpose (as it were) graffe them lyke a graffe of a tree in a more luckye stocke, to make them more sightly and faire. ${ }^{90}$ His language is embellished, full of artifice. Indeed in the Italian renaissance, as Wayne Rebhorn points out, the concept of 'artificioso' was not one of opprobrium but one of praise. ${ }^{91}$ In England it tended, on the whole, not to bear this positive connotation except in poetic and courtly circles.

By the 1590s, there was direct confrontation with the Castiglionian model, probably resulting from the disorder and cleavages evident in the late Elizabethan court. John Marston satirised the 'perfum'd Castilio' (a direct swipe at Castiglione's imitators) who 'Nere in his life did other language vse / But, Sweete lady, faire mistres, kind hart, deare couse' ${ }^{92}$ Even more damningly, in Pygmalions Image, he called the type the '[b]roker of anothers wit' who, for all his 'fine sette speeches' 'doth but champe that which another chew'd'. In his scathing opinion, the much-feted courtier was an empty shell. 'Take ceremonious complement from thee / Alas, I see Castilio's beggary. ${ }^{93}$ Edward Guilpin writes in the same vein about London apes, one of them 'all court like' in Spanish clothes, who is a veritable 'Dictionary of complements, / The Barbers mouth of new-scrapt eloquence [...] And Madame conceits gorgeous gallerie', the 'exact pattern' of a man which 'Castilio / Tooke for accomplish Courtier' ${ }^{94} \mathrm{He}$ is in no doubt of his influence on the nerve-centre of English life: 'Come to the Court, and

89 Rebhorn 1978, p. 14.

90 Castiglione 1561 , sig. fiiiiv .

91 Rebhorn 1978, p. 40.

92 Marston $1598 \mathrm{a}$, sigs. B ${ }^{\mathrm{r} v}$.

93 Marston 1598 b, p. 30.

94 Guilpin 1598, sig. $\mathrm{D}^{\mathrm{r}}$. 
Balthazar affords/ Fountains of holy and rose-water words. ${ }^{95}$ When Nashe in 1594 spoke out scathingly against 'Filthie Italionat complementmungers' who exerted themselves only to be counted 'the Courts Gloriosos, and the refined iudges of wit', he was in his own way resisting the Englishing of an ideal of speech and behaviour which Thomas Hoby had undertaken for the first time in his translation of Castiglione in 1561, and which had received new leases of life in the editions of 1577 and 1588 . One may argue that what he was really resisting was the travesty of such an ideal but in any case, the result was the same: the cortegiano had apparently proved 'welwilling to dwell in the Court of Englande', but whether he really was an Englishman was more in doubt. Typically, the upstart in Nashe's Pierce Penilesse had used a non-native mode of speech as a means of social ascent. His talk 'Al Italianato' came at a price however; almost axiomatically he was said to despise 'the barbarisme of his own Countrey'.96 Undoubtedly, Gabriel Harvey, the would-be courtier and erstwhile follower of the Earl of Leicester's circle, was not far from Nashe's mind at any stage. He was one of the particular individuals who would earn the dubious reputation as an antitype of English nationality. He was the ultimate soft target. Significantly, Harvey was a well-known admirer of Castiglione. In Cambridge, he had advised his students to read The Courtier and there is evidence that he was fascinated by the concept of sprezzatura, noting it assiduously in the margins of his own copy of the book. ${ }^{97}$ Nobody could have been less of a model of the desirable nonchalance. He earnestly tried to acquire all the trimmings of foreign civility.

On one occasion, when the memorable controversy between Nashe and Harvey was waxing high, the former recalled an incident showing the foreign measure of Harvey through and through. In Audley End in 1578, dressed in velvet, and vying inelegantly for favour, Harvey had delivered a flowery complimental oration, kissed the Queen's hand, and was told that he had quite the air of an Italian. According to Nashe, he took it as an encouragement to renounce 'his naturall English accents and gestures' and wrest himself 'wholly to the Italian puntilios, speaking our homely Iland tongue strangely as if he were but a raw practitioner in it, and but ten daies before had entertained a schoole master to teach him to pronounce it'. It was his condemnation. To be 'alwaies abroad and neuer within' in

95 Guilpin 1598, sig. $\mathrm{C}_{4}{ }^{\mathrm{r}}$.

96 Nashe 1594a, sig. Diij ${ }^{\mathrm{v}}$; Castiglione 1561, sig. Aiiir ${ }^{\mathrm{r}}$; Nashe 1592a, sig. B1v

97 Stern 1979, pp. 158-161. Paradoxically, Harvey could also criticise the over-emphasis on courtesy books among Cambridge students. Harvey 1884, 78-79. 
terms of one's speech, habit and behaviour, was to be, in a word, 'like a begger' ${ }^{98}$ It was to be, in other words, subservient and dependent - quite simply not to be oneself. In showing up the advantages of recollection and collectedness by criticising their opposites, there is more than a tinge of Stoicism to such remarks. This ought not to surprise us. The vocabulary of neo-Stoicism was, as we have established, a pervasive one in late sixteenthcentury England; that it should enter into presentations of an ethos of national self was inevitable.

The ultimate parody of Italianate forms came from the contemporaneous pen of Greene. It is quite possible that he intended the character of Velvet Breeches to be a riposte to Hoby's all too complacent acceptance of the courtier into English life, or at least a reaction against the multitude of cheap imitations that had sprung up in its wake. The character's boastful declaration that he is 'cald into England from my natiue home [...] to honour your countrie and yong gentlemen here in England with my countenaunce' is eerily reminiscent of the preface to Hoby's translation which only four years previously had run into a third edition. There the words of the now dead translator had rung out again, words triumphantly declaring that the courtier 'is beecome an Englishman (whiche many a longe tyme haue wyshed, but fewe attempted and none atchieued) and welwilling to dwell in the Court of Englande, and in plight to tel his own cause'. Greene appears to be deliberately mocking this, by letting such a one tell his 'cause' in the most distinctly unflattering light possible, and exposing it for what it is, an unwarranted and unpalatable intrusion: not a natural cause at all but a trumped-up foreign one. ${ }^{99}$

The character's speech is characterised by two principal features which show him up to be the caricature of the Italianate courtier posing as an Englishman. Firstly, it is a language of unwarranted hyperbole: he compares the brilliance of his heritage to sunshine and the baseness of his opponent's to mere candlelight, for example. Moreover, the terms in which he states his claim to England are typically overstated. 'The rights and title in this country [...] fauours me, I am admitted viceroy'. As the narrator says to him: 'you claime al, he [Cloth] would haue but his owne'. ${ }^{100}$ His opponent is quick to mock him for his inflated language,

98 Nashe 1596 , sigs. $\mathrm{L}_{4}^{\mathrm{v}}, \mathrm{M}_{2}^{\mathrm{v}}, \mathrm{Mi}^{\mathrm{v}}$. The $O D N B$ situates this incidence in Hadham Hall, Hertfordshire rather than Audley End. Nashe $1592 \mathrm{~b}$, sigs. $\mathrm{D}_{2}{ }^{\mathrm{v}}, \mathrm{F}_{4}{ }^{\mathrm{r}}$ also gives an account of the incident, and calls Harvey a 'Braggadochio Glorioso'.

99 Greene 1592a, sig. B1v; Castiglione 1561, sig. Aiiir.

100 Greene $1592 \mathrm{a}$, sig. B2v . 
addressing him as 'Signior Glorioso' and 'Mounsier Malapart', whereas he, the true Englishman is not addressed at any stage in an especially formal way. This detail is highly realistic: Peter Burke has noted the increased use of honorific terms of address in sixteenth- and seventeenth- century Italy, and the practice apparently went against the familiar grain of English behaviour, at least according to Peacham, who, although no general opponent of continental customs, took exception to the Neopolitan custom where 'every base grooome [...] must be termed Signore', to the Venetians for calling every 'mechanique' a 'Magnifico', and to the French where every peasant is 'saluted by name of Mounsieur, or Sire '.101 Inflation rather than honesty was the baseline of fashionable courtesy. True English nationality was compatible with a recognition of proper social distinctions - at the same time, writers felt England to be a less inegalitarian country than abroad. ${ }^{102}$

The other problematic feature of Velvet's speech is his flexibility, his 'souplesse' with the truth. He has referred to England as 'my land' even though he is obliged to confess a little later that he is still a 'stranger in this land' and has, in fact, only just arrived. It is thus ironic that the legal terms of the case state that Cloth Breeches has done Velvet 'disseison of franke tenament': frank is precisely what the latter is not and frank tenement (freehold) was a historically and politically weighted idea in a legal context. His lack of free tenure in the country is subsequently borne out by the decision of the jury. ${ }^{103}$ His mendacity is at its most blatant however when he makes a reappearance in Barnabe Rich's pamphlet the following year outside the gates of heaven. For the particular Petrine examination that ensues, it is apparently important to prove one's authenticity, in which national credentials play a vital part. So after ascertaining his name, St Peter's next question is to find out his provenance, and in this supreme moment when his eternal fate hangs in the balance, he claims to be an Englishman - apparently unable to change the habits of a lifetime by telling the truth. Peter is not deceived; he cannot think him to be a 'naturall Englishman' for he has never heard of any of that name in the country. ${ }^{104}$ Having lived a lie, Velvet's final lie damns him. Although this is the theme of imposture carried to a ludicrous level, it nonetheless illustrates the unease which was felt about the potential of Italianate forms of speech in an English context. Both authors want to stress in their serio-comic way

\footnotetext{
101 Greene 1592a, sig. B2r ${ }^{r}$; Burke 1993, p. 19; Peacham 1622, p. 15.

102 See below, pp. 132-133.

103 Greene $1592 \mathrm{a}$, sigs. $\mathrm{B}_{2}^{\mathrm{v}}-\mathrm{B}_{3}{ }^{\mathrm{r}}, \mathrm{F}_{3}{ }^{\mathrm{v}}-\mathrm{F}_{4}{ }^{\mathrm{r}}$.

104 R[ich] 1593, sig. C1v .
} 
that this courtier with his inflated language, so trumpeted by the great and the good, does not match up to older traditions of plain speaking and living.

The overarching sartorial metaphor of these works will be examined later but it is important to note that clothes and speech were constantly overlapping into each other's territory, especially in the depiction of foreign courtliness. As language is the expression of the mind, clothes are the expression of the body. Verbal self-presentation and self-fashioning went together. Excessive language is like excessive clothing. The best collocation fusing the two is the collocation 'velvet terms'. The new language was soft and luxuriously insidious. This image is invoked in The pleasant comodie of patient Grissill, a play jointly written by Thomas Dekker, Henry Chettle and William Haughton, based on the Boccacian and later Chaucerian tale but with highly-charged contemporary allusions. Although ostensibly set in Italy, this is a convention, as Michele Marrapodi affirms, in which many dramatists chose to present truly domestic concerns. Another example from the same source is of a similar ilk: he speaks of 'silke gallants' who 'speake no language but sweet Lady, and sweet Signior and chew between their teeth terrible words, [...] as complement and Proiects, and Fastidious'. ${ }^{105}$ Such 'terrible' words have long since become commonplace, but for a traditionalist at the time, they were anathema. They were convoluted, degenerate, unplain: the very luxuries rather than the core of a lexis. John Marston, who was only starting his career with the first sortie into satire for which he would become most famous, presented a mock-conversation between the long-sighted Linceus (i.e. the lynx) and an Athenian cynic in The Scourge of Villaine, in the course of which he took the measure of the sumptuously-attired gallant complete with French herring-bone pattern, and 'new-stampt complement': the Gallic provenance of his clothes being matched perfectly at the level of discourse. The 'stamp' of both is artificial and inorganic. ${ }^{106}$

It was, in fact, impossible for contemporaries to see matters of speech and dress as discrete domains. The strong-minded woman in one of Roger Sharpe's epigrams, belonging to his only collection entitled More fooles yet refuses to marry her fine-tongued suitor, because his fabricated compliments reveal him to be insufficiently her compatriot.

105 [Dekker et al.] 1603, sig. Civ. Marrapodi et al. 1993, p. 9.

106 [Marston] 1598, sig. F2 $^{\mathrm{r}}$. 
Ile marry none except an Englishman:

If you are, as you seeme not by your speaches,

Reserue your Fustian for to patch your breeches. ${ }^{107}$

The sting of the rider depends on knowing, of course, that much of the grey-brown fustian came from Genoa and Milan. ${ }^{108} \mathrm{~A}$ similar way of thinking is to be gleaned from an allusion made by the Calvinist minister, Thomas Adams, in a sermon on flattery, the second in a series entitled The Deuills Banket. He weighed in against the 'Italianate Apes and French Parrats' as ones who could 'spinne themselues silken sutes on the voluble wheeles of their pleasing tongues'. The circuitry of the spinning motion happily conjured up all the redundant emptiness of such conversation and although Adams was not making a direct point about being English - his treatment of flattery is one part of a much longer treatment of the vials of $\sin$ - the usage of such an image in such a context is especially revealing, in that it shows how engrained a motif it was for him to be able to confidently expect it to resonate with his hearers and discomfit them. ${ }^{109}$

One of the worries about dressing up words was that, being effeminate, it would have a negative impact on the military standing of the country. John Stephens' in his essay on cowardliness, dismisses '[ $t$ ] hose which haue onely complement': he says that when challenged, they 'quake' with fear. All their swaggering bravura is worth nothing. ${ }^{110}$ This is brought out again some years later by Ralph Knevet in his Stratiōtikon, or, A Discourse of Militarie Discipline, part verse georgic, part instruction treatise on the cultivation of 'this Art of order' for men of the nation. Standing in the way of such good order were 'Monstrous abuses' such that 'Mounsieur' and the English gentleman were fast becoming indistinguishable. He writes:

we our selues, our gestures, and our swords,

In French are drest vp; yea our very words,

Haue put on French dissimulation. ${ }^{111}$

$107 \mathrm{~S}$ [harpe] 1610, sig. $\mathrm{D}_{4}^{\mathrm{r}}$. There is a related judgement on the language of wooing in Shakespeare's Love's Labour's Lost as Berowne in the final scene repents of wooing in rhyme and 'Taffeta phrases, silken terms precise, / Three-piled hyberboles, spruce affectation' and instead vows to henceforth express himself in 'russet yeas and honest kersey noes'. Worthiness versus affectation is probably more on Shakespeare's mind than Englishness, but it is interesting that he chooses to phrase it in just such a way. Shakespeare 2002, V.ii., p. 242.
108 Dietz 1972, p. 143.
109 Adams 1614, pp. 69, 45-46.
110 Stephens 1615, pp. 9-10.
111 Knevet 1628, sigs. $\mathrm{F}^{\mathrm{v}}$, $\mathrm{F}_{2}{ }^{\mathrm{r}}$. 
Dire consequences are subsequently outlined in a passage riddled with classical allusions, the main one warning of the fate of King Darius whose adoption of a Greek-style sheath for his sword was prelude to the Achaemenid Empire's defeat at their hands. To an extent, it was a traditional worry that a preoccupation with the finer sides of life might make the adult male do his duty badly in times of war or neglect it altogether. ${ }^{112}$ But this was a very particular, not just a general dread: the image evoked memories of the humiliating defeat suffered by the Duke of Buckingham's expeditionary force on the Île de Ré off La Rochelle in October 1627. How could one secure victory, such logic went, if one had already ceded the moral victory by digesting, or more appropriately 'donning' the enemy's ways and serving as a mouthpiece for their very words?

Another domain of imagery for redescribing courtesy as unwanted foreign encroachment was that of infectious disease. Thomas Jordan, with all the vivid imagination of an actor-playwright, summed up the phenomenon in this way in his very popular verse miscellany Pictures of Passions, fancies, \& affections poetically deciphered, in variety of characters.

We draw so much our Neighbouring

Air of France

That Complement (like an Inheritance:

Is Native) like Diseases of succession,

And sticks, as close as primitive Transgression.

Compliment has been inherited by the 1641 generation and adheres as closely as original sin: it transforms the senses of those who are exposed to it into a 'healthlesse waste'. ${ }^{113}$ Every generation is now 'born' into this pestilent air from France. It was almost as if French compliment had gone native in England, almost but not quite. The whole point of original sin was that it was not, in a sense, original: there was a state which preceded it, and this is what he is obliquely recalling. Jordan's lament is particularly interesting for us because he has none of the radically Calvinist sympathies or grudging anti-monarchical attitudes which might make antipathy to France more pronounced. He writes, knowing full well that the court has been Frenchified, but remaining devotedly royalist at the same time.

The last two examples, coming from the latter part of the period, with their focus on French, are particularly apt because by then, it had become

112 Rebhorn 1993, p. 245 makes the point that Castiglione himself is acutely aware of this danger in his presentation of the courtier, something that makes him insist much on the masculinity of the figure.

$113 \mathrm{~J}$ [ordan] 1641, sig. $\mathrm{C}_{3}^{\mathrm{r}}, \mathrm{C}_{2}^{\mathrm{v}}$. This miscellany was issued twice in the same year. 
the main source for complimental discourse. Rich objected to the way in which obsequious declarations like 'at your seruice [à vo(s)tre service], at your commaund, at your pleasure' had eclipsed the 'olde protestation, Yours in the way of honestie', which, he claimed, had a directness and a singular absence of ceremony about it. Brathwaite had the same sort of contrast in mind when he criticised the returned traveller for being 'all for your Seruants Seruant' and 'titles of lowest observance'. There was a shifting away from simplicity to more superficially civil modes: Jordan diagnoses it as false humility. ${ }^{114}$ The new phrases, besides being far too elaborate for their purpose, smacked of subservience, and were (potentially at least) hypocritical. That may have suited the French but not the English. Nashe expressed it so:

The Frenchman (not altered from his owne nature) [...] though he be the most Grand Signeur of them all, he will say, A vostre seruice \& commandemente Mounseur, to the meanest vassaile. 115

Equalising the unequal by false language was simply another way of abusing meaning. Plainness recognised true social distinctions.

The most politicised of the accusations against these clumsy transpositions had been meted out by John Stubbes in the course of The discouerie of a gaping gulf. Imagining the antic speech of the Duc d'Anjou, he reports him as saying: 'Syr I yeeld my selfe to you to dye at your feete, in your seruice, assuring you that neuer vvill I be estranged from you'. The tone is one of self-abasement, entirely disingenuous however. ${ }^{116}$ Later Stubbes pushes the point home, by envisaging a situation in which Anjou will appoint some of his own men 'to serue hyr [Elizabeth] and be at her commaundement after the french phrase' while he goes away to attend to other business. But this courtly-sounding phrase 'at her commaundement', translates 'in playn English' as the very opposite of what it seems, foreign domination over her and her state. To translate properly was to deconstruct: to separate 'surface' talk from substance. ${ }^{117}$

114 Rich 16o6, fo. 6v . He would return to these expressions in Rich 1616, p. 5o, dismissing them as 'Fustian phrases'. [Brathwaite] 1631b, p. 153. Another example of the hostility aroused by usage of the phrase 'at your service' and of the general propensity to swallow the 'new Congye, or protestation' is to be found in Cornwallis $1600-01$, sigs. $\mathrm{L}^{\mathrm{v}}, \mathrm{N}_{3}{ }^{\mathrm{r}}$. J[ordan] 1641, sig. C2 ${ }^{\mathrm{r}}$.

115 Rich 16o6, fo. 6v; Nashe 1592a, sig. C1 ${ }^{\mathrm{r}}$; King 1941, xx; Nevalainen 1999, p. 370; Prins 1952, p. 41. Cleland, an Anglophile Scot, also objected to: 'I kiss your hand Sir, and I am your most humble servant'. Cleland 1607 , p. 177.

116 [Stubbes] 1579, sig. $\mathrm{B}_{4}^{\mathrm{r}}$.

117 [Stubbes] 1579, sig. $\mathrm{C}^{\mathrm{v}}$. 
Notable by its absence in all these elegant speech patterns was plainness. To ask to what extent these satirists and critics were deliberately going about advocating an ideal of plainness is perhaps the wrong question to ask, for in most cases, they were much readier to point the finger at what they did not approve of, and less ready to eulogise on what they did. Nevertheless, it is reasonable to infer that their negative tirades implied some sort of intuition - whether definite and stated or hazy and ill-defined - about what it was that ought to constitute the English speaker of whatever social category. Certainly, in one of Samuel Rowlands' forceful epigrams, there was nothing remotely hazy about what he thought the gallants of the day were missing.

Most admirable be the wordes they speake,

T'expresse their mindes plaine English is to weake

To these strange words, which the braue gallants cogge

A courtly conge is the Epilogue. ${ }^{118}$

The mention of a congé indicates that an important dimension of communication was gesture, an accompaniment to speech and so much else besides.

\section{DisCOURSING GESTURES}

If how one spoke was important, how one 'spoke' oneself was nowhere more clearly seen than in how one disposed of one's own body and the expressions of one's countenance: the doing so invariably amplified one's capacities for expression. Gesture, involving in its widest sense, posture, gait, physiognomy and movement, is still an emerging field of study and its meanings in context are only starting to be uncovered by historical ethnographers. The project is to recover how 'times, spaces, identities and roles are enacted within a given culture' as Michael Braddick announces in a seminal collection of essays on the subject. ${ }^{119}$ A comprehensive history of gesture in early-modern Europe is still waiting to be written but Peter Burke has raised an intriguing hypothesis to the effect that two distinct gestural cultures emerged during the sixteenth century, geographically divided between that of the restrained forms of self-expression belonging to the peoples of Northern Europe, and the more flamboyant

118 [Rowlands] 1605, sig. $\mathrm{A}_{3}^{\mathrm{r}}$.

119 Walters 2009, p. 122. 
ones associated with the Catholic South. ${ }^{120}$ It is certainly a thesis worth bearing in mind as we consider ideas about national gesture. John Walters has done some work on gestural codes in early-modern England in their relationship with hierarchy and social status, but as yet, little consideration has been afforded to the consideration of prescriptive national codes. On the ground, of course, the lived experience of people was much more likely to present gestural 'dissonance and dissent' than unity and harmony and we can decipher this too from the works that we shall consider. $^{121}$

It will be helpful to frame the discussion in a theoretical work, even though it comes towards the end of our period, as this is evidence for a certain maturity in thinking about the meaning of gesture. John Bulwer's Chirologia: or, The natvral language of the hand composed of the speaking motions, and discoursing gestures thereof of 1644 reflects a wider European movement which sees gesture as a universal language, capable of bringing men together. He and those of his ilk believe that the hand should learn to speak all languages, as is so natural to it. Nevertheless, even within his harmonious universalist vision, there is a place for distinctive national idioms, or, what he calls, Chirethnicalogia. ${ }^{122}$ He makes claims to a certain balanced objectivity: declaring blandly in the introduction that he will take into account the 'fashions of divers Nations in their national expressions by gesture.' Yet his ethnography of gestures is judgemental rather than merely descriptive, and as such, it betrays his own assumptions and convictions, however tolerant he is compared to other commentators.

He asserts that there is such thing as a standard of 'Nationall decorum' which is imposed upon men by their 'time and place'. This decorum comes from the particular 'Genius of that climate' and determines what may or may not be done with appropriateness there. He is quite able to countenance wide discrepancy in standards of a 'golden Mediocrie'; yet his judgement is sharp when it comes. Italians were prone to 'overmuch gesturing with the Hand': that is considered proper there. In France, he slyly noted, one is 'not a la mode, and a compleat Mounsieur, who is not nimble in the discoursing garbe of his Hand'. We note the fluidity of the metaphor: gesture was seen as a way of clothing the body, and therefore also

120 See Burke 1991, pp. 71-81 on Renaissance Italian gestural cultures; Knox 1990, pp. 101-36 on gesture and universal languages in the seventeenth century.

121 Walters 2009, p. 122.

$122 \mathrm{~B}$ [ulwer] 1644, sig. A2 ${ }^{\mathrm{v}}$. Unlike his extensive treatment of both the Chirologia and the Chironomia (rule of hand), he does not devote a whole section to the Chirethnicalogia, but rather a cautionary. This is announced in $\mathrm{B}\left[\right.$ ulwer] 1644 , sigs. $\mathrm{A} 7^{\mathrm{v}}-\mathrm{A} 8^{\mathrm{r}}$. 
of concealing it. Typically, the preferred movements of the French were proportionate to their language, he adds, being brisk and 'lightsome'. The Spanish standard of moderation in gesture was different again, being proud and lofty: hands are 'accessories to their proud expressions'. Thus although in theory he grants these nations their measure of decorum, in practice he undercuts it, by re-describing them as excessive. Predictably it was only the English and the German who valued true 'moderation and gravity' because of their 'Nationall complexion'. Clearly, their mode of gesture fits in best of all with his earlier conviction that it should be a liberall and free Index of the Minde', and that there should not be a 'too daring garbe of action' on the one hand nor a rustic timidity on the other. ${ }^{123}$

There is one glaring sense in which Bulwer differs from much more partisan contemporaries. Unlike them, he proceeds to endorse a convergence of national idioms. He notes that because the English have borrowed so many words and thus enriched their language, they may also, as long as moderation is observed, 'with decorum and gravitie enough [...] Meet the Hand of any of these warmer Nations halfe way, with the Manuall adjuncts of our expressions'. ${ }^{124}$ Three points must be made a propos. First, we note that the Englishman does not forsake his innate values of moderation. He meets the hand of other nations frankly: it is not a servile connection of bowing and scraping. Secondly, we note the hint of the climatological motif: warmer nations are deemed to be more flamboyantly gestural because passionate; cooler nations more aloof, corresponding to their greater fidelity to reason. It is yet another dimension being taken into a national ethos of plainness. Lastly, for all its caveats, this is a cautious acceptance of the 'indenization' of foreign gesture and as such, a rare statement. As the last words of the whole treatise, apart from a final verse, these have something of the effect of a challenge. No doubt some such amiable compromise best describes what was actually happening among elites, but in the writings of the day, it was far more common to find denunciations of the practice of combining gestural idioms, whether by the manner in which one registered emotion in one's face, carried oneself, greeted one another, and moved.

The true Englishman ought to bear himself in public, Brathwaite said, with a 'Sober carriage or deportment of the Body' and know that in so

$123 \mathrm{~B}$ [ulwer] 1644, sigs. A $7^{\mathrm{v}}-\mathrm{A} 8^{\mathrm{r}}$. pp. 144, 145. An interesting corrective to this view of the French is provided in D'Estienne 1980, p. 323: 'les Françés ne sont pas gesticulateurs de nature'.

124 B[ulwer] 1644, pp. 144-146. 
doing so he was adding 'no little lustre to Discourse' itself. The accompaniment of speech with needless nods and gestures was considered a form of 'phantasticke imitation or servile affectation' that betokens a 'degenerate qualitie or disposition.' ${ }^{\prime 25}$ Stradling, embroidering upon Lipsius, urged that Englishmen be not 'plaiers on the stage' mimicking a 'dosen kindes of gestures'; Peacham that they use 'comely moderation' in countenance and gesture. ${ }^{126}$ In an era starting to be fascinated by physiognomy (although it was not until the work of Johann Kaspar Lavater in the eighteenth century that the subject became really popular), we note that certain facial expressions were read as indications of a man's loss of Englishness. Contortion of feature was emphasised: Nashe's 'dapper Iacke' whom we have seen in action before, had taken to 'wring[ing] his face round about, as a man would stir vp a mustard pot', in a misguided attempt at sophistication. ${ }^{127}$ Brathwaite's mockery of the 'scrude face' was surely referring to the same phenomenon. ${ }^{128}$ The set of one's lips even before one framed words could also pose problems because some thought that the mouë typical of the French was unsuitable for English speakers. Cotgrave, in his bilingual dictionary of 1611, could not refrain from judgement, calling it 'an (illfauoured) extension or thrusting out, of the lips'. ${ }^{129}$ Rich saw it too as an inappropriate acquisition on the part of the traveller and in a later description of a fantastique 'marke[d] but his countenance how hee mops, how he mowes, and how he streines his lookes'. ${ }^{130}$ Not only were these expressions disliked in themselves, but they were further confirmation, if confirmation was needed, of this ambiguous creature's dissatisfaction with everything at home. The 'affectate Traueller' censured 'all things by countenances, and shrugs', Overbury noted, while Howell, referring to the same breed of people, observed that even if they could not talk in a foreign way, they made up for it 'by head and shoulder, magnifying other Nations, and derogating from their own'.131

The mention of shrugging directly raises the question of Italian influence. It was almost universally despised, and the traveller was urged not to bring it home, notably by Robert Dallington, who, although he would

\footnotetext{
125 Brathwaite 1630 , p. 87.

126 Lipsius 1592, sig. C2 ${ }^{\text {r }}$; Peacham 1622, p. 42.

127 Nashe $1592 \mathrm{a}$, sig. $\mathrm{B}^{\mathrm{r}}$.

128 Brathwaite 1631 , p. 97.

129 Cotgrave 1611, Mot-Mov, sigs. Hhhr-iiijv . Monnoye de Singe (literally the monkey's money) was a colloquial expression in French which was translated into English as moes, mumps, or mouths. Mon-Mon, sigs. $\mathrm{Hhh}^{\mathrm{r}} \mathrm{ij}^{\mathrm{r}}$.

130 He dismissively calls it the mump. Rich 1606 , fo. $8^{\text {r }}$. Rich 1616, p. 51.

131 Overbury 1616, sig. D1 ${ }^{\mathrm{r}}$, Howell 1642 , p. 175 .
} 
rather see the Englishman Italianate than Frenchified in other ways, weighed in emphatically against the transposition of their 'huffe of the shoulder'. ${ }^{32}$ For Harvey, the 'Italish' look and the 'cringeinge side necke' were among the gestures that had changed the Englishman into a minion. ${ }^{133}$ That he should be so vehement when he was accused of the very same defects is one of the many piquant twists in the Harvey tale. Nashe, with characteristic vehemence, is referring to the same gesture, when satirising the Englishman for learning to 'cringe his neck like a starueling', literally like someone reduced to a condition of begging, forced to be suppliant. ${ }^{134}$ This touches on some interesting resonances: in ancient Greece, the word for beggar was closely related to the word for hare, deemed to be a cowering animal; and Nashe in his own way is part of that tradition in representing the slavish as physically as well as morally different to the upright citizen. ${ }^{135}$

On a larger scale, there was a degree of controversy about whole body movements which had, under foreign influence, become customary when greeting or taking leave of one another. Mirroring the language of compliment, what one witnesses in Renaissance and post-Renaissance courts is a huge elaboration of gestural codes. The elaboration achieved two things. First, it was an enactment of the relationships of power and subservience that characterised the hierarchical structure of the court. Secondly, it created a complex, even opaque system of 'usages' which none except the initiated could confidently use. One had to learn to perform what was required in particular settings. There was no place for naturalness or spontaneity. As people sought to emulate their social superiors, these ways of deporting oneself trickled downwards in society: they were not just found within the locus of the court. Rich's waggish 'you shall know them by their salutations' became something of a truism for the whole period. ${ }^{136}$ It is difficult to reconstruct the physical accompaniment of traditional English greetings because they talk so very little about them. The two possible reasons for this silence lead us in two different directions. Perhaps it was because they were taken so much for granted that they did not have to. As Braddick observes, it is the 'inexplicit or unstated meaning of action or utterance' that 'discloses the cultural frame to the observer.' 137 If things

\footnotetext{
132 Dallington [1605?] sig. B $4^{\mathrm{r}}$. See also Rich 1606 , fo. $8^{\mathrm{r}}$; Rich 1616, p. $5^{1}$

133 Harvey 1884, p. 98.

134 Nashe 1594 b, sig. L4 ${ }^{\mathrm{v}}$.

135 Bremmer 1991, pp. 25-26.

136 Rich 1606 , fos. $6^{\mathrm{r}}-6^{\mathrm{v}}$.

137 Braddick 2009, p. 9.
} 
are unsaid, it also answers our purpose. Alternatively, one could put forward that perhaps customs were not sufficiently established or standardised to make any appeal to them resounding. In any case, the 'Europeanisation' of social preliminaries was, it would seem, being contrasted with some more naturalised English code. This was probably a half-fanciful construction; nevertheless one catches glimpses of what might once have been the case. Rowlands' Signeur Fantastique, we learn, scorns the traditional 'good morrow and good deane', whilst Brathwaite does mention that the returned traveller scornfully resalutes the 'common congie' and 'jeeres at our complement'; frustratingly, neither quite specifies what gestures are included in these formulae, if any at all indeed. ${ }^{138}$ It was apparently clear to many, like Cornwallis, that 'we of these latter times, full of a nice curiositie, mislike all the performances of our forefathers, we say they were honest plaine men'.139

When it came to the adoption of lavish reverences, there was thus an acute reaction on the basis that they were not truly native. Rich described the new formula as tripartite, consisting of a kiss on the hand, a full reverence of the whole body, and an extension of the arms. ${ }^{140}$ The two first elements provoked the most abuse. It is not altogether apparent whether it entailed joining the fingertips of the right hand and bringing them to the lips as one historian suggests, or the kissing of one's forefinger according to Harvey, or the kiss of the back of the other's hand, according to Bulwer and Jordan. ${ }^{141}$ In truth, all the variants probably overlapped. Fashions were as mobile here as elsewhere. It was the Arabs who were said to have originally given the Spaniards their 'usuall formes of salutation and valediction whose complement usually is Baso les vostres mans, I kisse your Hand' in the middle ages; by the sixteenth century, it had become customary in Italy too, and then elsewhere, so much so that there was 'no expression [...] more frequent in the formalities of civil conversation'. ${ }^{142}$ The transposition of this custom made the Englishman 'like an ape',

\footnotetext{
138 [Rowlands] 160o, sig. B2 ${ }^{\text {r; }}$ [Brathwaite] 1631b, pp. 152, 151.

139 Cornwallis $1600-01$, sig. P6 ${ }^{\mathrm{r}}$.

140 Rich 1606 , fo. $6^{\mathrm{v}}$.

141 Flachskampf 1938, p. 221 mentions this gesture but does not provide historical contextualisation. Baüml and Baüml 1975, p. 181. Harvey 1884, p. 98; B[ulwer] 1644, p. 122; Jordan 1641, sig. $\mathrm{C}^{\mathrm{r}}$.

${ }_{142}$ B [ulwer] 1644, pp. 122, 87. Eliot 1593, p. 3 also notes it. There is evidence to suggest that kissing on the cheek was customary among the English in the medieval era. Erasmus noted it in 1499. See Hill 1893, p. 302. Perhaps this had gone out of fashion by the seventeenth century; or perhaps it was the foreign manner of kissing that was problematic.
} 
according to Nashe. ${ }^{143}$ Rich was particularly set against its frequency: his 'Flowres of courtesie' were 'so frequent with the kisse on the hand, that a word shall not passe their mouths, till they haue clapt their fingers ouer their lippes'. ${ }^{44}$ Previously in Greenes Newes, Velvet Breeches had speculated upon giving the 'Baselos manes' to monarchs and princes when he gets to heaven, a capacity that he never gets a chance to prove. ${ }^{145}$ Often cited in Spanish, it is plausible to argue that this may have been because the mannerism was considered so very un-English that it was not possible to fully integrate it into the language, let alone the culture.

There is a tendency, as old as anti-aulic satire itself, to couch the courtier's carriage and deportment in the language of physical deformity, and this is fully the case here. To represent him 'full of creeping and crowching' was not only to make a point about his moral nature but also about the extent to which he had departed from national norms. ${ }^{146}$ Prostration, as Walters observes was 'not something to which free born Englishmen willingly subjected themselves to.' Or at least, they ought not subject themselves to it. The convergence between the style of the court and foreign ways was nowhere more keenly felt: in both the Englishman 'must licke, he must croutch, he must cogge' if he wished to come to preferment. ${ }^{147}$ For the disenchanted English earl in Nashe's The Unfortunate Traveller who had made this observation, the first particular effect that travel in Italy had on the young Englishman was to change his salutes into an esoteric game: he now 'play[s] at heypass, repass come aloft', making what ought to have been a simple transaction into something approaching a conjuring trick. It is not insignificant that this rather gloomy observer goes on immediately to list the more serious vicious influences; while gestures have no moral content in and of themselves, it is as if they act as the highroad to other kinds of immorality - atheism, epicureanism, prostitution, poisoning, and sodomy. Once one has entered into an Italian way of being even on a superficial level, there are no limitations as to how low one can descend. ${ }^{48}$ On other occasions, what drew Nashe's satirical eye was the fact that the

\footnotetext{
143 Nashe 1594b, sig. L4v .

144 Rich 1606 , fo. $6^{\mathrm{v}}$.

145 R[ich] 1593, sig. B1v ${ }^{\mathrm{v}}$. See also Lodge 1596, p. 20; Cornwallis $1600-01$, sigs. N3 ${ }^{\mathrm{r}}, \mathrm{P6}^{\mathrm{v}}$; [Rowlands] 1605, sig. A3 ${ }^{\mathrm{r}}$; Rich 1616, p. $5^{1}$ for further satiric references to this practice. For Haughton 1616 , sig. $\mathrm{B}_{2}{ }^{\mathrm{v}}$ it is the Frenchman who never washes his fingers, but licks them clean with kisses.

146 Rich 1606 , fo. $6^{\mathrm{v}}$.

147 Walters 2009, p. 107; Nashe 1594b, sig. L3 ${ }^{\mathrm{v}}$.

148 Nashe 1594 b, sig. L4v ${ }^{\mathrm{v}}$.
} 
bow had practically become a genuflection, so that it literally meant scraping one's knees on the ground. This is the sense of the name Iaques Scabdhams that he gives to the Frenchified Englishman, and also of the gallic practice of swearing 'Ah parla mort Dieu' when their 'hammes are scabd,' something that must have happened all the time, and which of course was completely unnecessary. There was something decidedly obsequious about all these gallic bowings and scrapings. ${ }^{149}$ It was more generally noticed. In 1642, a Spanish doctor, Carlos Garcia writing a study of the differences in dispositions between the French and the Spaniard, the two 'great lights of the world', noted that when the Frenchman met a friend, he would 'salute him with his whole body, bending downe his head, kissing his hands, and making legs'. 150 The Spanish style had then become more rigid, and involved merely the doffing of the hat. Everybody had their bias.

Of particular interest are the staple references to the low bow as 'cringe'. Such a word created the impression of irrational not to say convulsive movement, leaving no trace of the residual elegance that might have rendered an expression of the sort attractive. It shows that many were not seriously prepared to engage with any so-called foreign practice. The gallant himself in Henry Hutton's collection of satires, whose 'nature doth vnfold / Him, to be framed in Phantastes mold' is aware that he will be satirised for, among other things, saluting 'a Mad-dame with a French cringe grace'. ${ }^{151} \mathrm{He}$ was right in that. Fitzgeffrey, who associated the French cringe with the dancing schools that coxcombs attended, remained distinctly unimpressed, while for Rich, to say that a fantasticke had 'the French Congé' sounded as if he had a disease. ${ }^{152}$ In a moment where faint praise was certainly damning, Brathwaite described his returned traveller as one with no 'uncomposed cringe to accoutre him'. Unknotting the negatives, the image suggests that rehearsed cringes were far worse than improvised ones, which would, after all, retain some spontaneity. For one's actions to have the dual demerits of being both effortful and ridiculous was surely the worst of all indictments. It was the polar opposite of

149 Nashe $1592 a$, sig. B2 ${ }^{r}$; Nashe 1594 b, sig. L4 ${ }^{r}$. See also Jordan 1641 , sig. C2 ${ }^{\mathrm{r}}$ whose gallant pays 'An homage [not only] to your Hand, but to your Toe'. Ironically, they may not have been long established gallic customs at all. Certainly, a few decades earlier, a French observer had blamed the introduction of the low reverence on the Italians, who conveniently figured for them as the source of all excess. D'Estienne 1980, p. 192.

150 Garcia 1642, sig. $\mathrm{K}^{\mathrm{v}}$.

151 Hutton 1619 , sigs. A6 ${ }^{\mathrm{r}}-\mathrm{A} 6^{\mathrm{v}}$.

152 [Fitzgeffrey] 1618, sig. $\mathrm{F}_{5} \mathrm{v}$; for accurate but hardly adequate discussion of dancing as a gentlemanly recreation see Vale 1977, pp. 88-93. Rich 1616, p. 51. 
sprezzatura. In much the same light are we to see Jordan's sly mockery of the Frenchified man's 'practick Cringe'. The whole performance made a meeting with friends an occasion for ludicrously dancing 'about his feet, And he 'bout yours'. ${ }^{153}$

What was so wrong with the entrée of 'outlandish congie or salute' into England? ${ }^{154}$ Fundamentally, it was thought to be a barrier to making those instantaneous judgements about the national identity of another. Salutations of their nature were ephemeral experiences, shared between strangers as well as acquaintances, so if one did not read common nationality in the performance of them, one might never know at all. A friend of George Whetstone, citing the 'plainesse' of his muse, warned him in verse of letting his gestures 'inforce thy friends to say / Behold a Frenchman, wher he flaunts, if face be turned away.' It was left to Knevet to express the dilemma most forcefully:

Our Postures are French conges, and few can:

Know Mounsieur, from an English Gentleman. ${ }^{155}$

The dilemma was thus greatly exaggerated, but the underlying argument is realistic. For him, there is no point in being an English gentleman if one cannot be recognised as such from one's bearing. Nationality has to be easily distinguished, not something to be thrown over at the first opportunity.

The second problem with these alien salutatory and valedictory gestures is that they are not appropriate to the English freeman. Although hierarchy is compatible with most visions of freedom then being articulated, there is also a clear sense in which hierarchy is seen in a restricted fashion: there is a feeling that it should be held back from overblown and irrational cultural expressions. Excessive gesture gave off the impression of obsequiousness and servility and put people in a position of subservience. Within this, there was the double suggestion that these gestures were slavish in themselves and also that it was slavish in the Englishman to copy them. The exiled English Earl whose jaundiced views are indicative of a popular point of view recognises the lamentable fact that

wee had rather liue as slaues in another land, croutch and cap, and bee seruile $[\ldots]$ than liue as frée-men and Lords in our owne countrey. ${ }^{156}$

153 [Brathwaite] 1631b, p. 152; Jordan 1641, sig. C2 ${ }^{\mathrm{v}}$.

154 Brathwaite 1630, p. 66.

155 Whetstone 1576 , p. 69; Knevet 1628 , sig. $\mathrm{F}_{2}{ }^{\mathrm{r}}$.

156 Nashe 1594b, sig. L $3^{r}$. 
The magnificoes' 'brave embrace to $\mathrm{y}^{\mathrm{e}}$ footewarde' was among the gestures that transformed the Englishman into a 'minion' according to Harvey, while similarly, in John Mennes' verse miscellany, one of the brisk epigrams depicts a Monsieur Congee who is so capable of discoursing with 'legs and quarter congees' for half hours at a stretch that he is not really to be considered a man at all. ${ }^{157}$ For the English 'Land-Lopers' who figure in Howell's treatise on travel, there was the barely-veiled connotation that to be overeager in the 'bending in the hammes' betrayed too great a readiness to yield. They returned loaded down with a virtual cargo of 'Complements and Cringes,' the superficial grace of the one offset by the patent servility of the latter. ${ }^{158}$ An element of anti-Popery is often added to the mix. Jordan's 'Complemental Man', for instance, who pays homage not just to hand but also to toe, is 'much suspected / To be a man that's popishly affected'. ${ }^{159}$ Gesture was Roman Catholic.

The practice of such low obeisance also carried with it the ever-present possibility of hypocrisy. Thomas Churchyard deliberately refers to making a leg and kissing the hand as a 'French deuice, nay sure a Spanish tricke'. Devices and tricks: the artifice was self-evident. Such 'lowting lowe' had no genuine meaning. ${ }^{160}$ The fullest treatment of this theme occurs in Samuel Rowlands' collection of epigrams and satires of 1600 entitled The letting of humours blood in the head-vaine whose vulgarity won him notoriety. ${ }^{161}$ Much of the work is devoted to mocking the humours of the 'late Crown'd King of Caualeers' and among manifestations of the type, Politique Peter is prodigal in lavishing 'French embracements by the score' and saluting 'about the Knees and Thighes'. In a previous satire, Rowlands spoke more clearly about the insincerity of such mannerisms. In the old times, a 'God saue you sir' would still bring down a grace on an enemy as on a friend, but the problem with these 'French congés' was that even if one did them perfectly, they revealed nothing at all of one's interior disposition. One might, in his words, combine 'inward hate' with 'outward salutation'. There is a sort of Geertzian apprehension of gestural ambiguity here: is the contraction of the eyelid a twitch or a wink, or indeed the parody of a wink? ${ }^{162}$ How is one able to tell? One isn't. That is precisely the problem.

157 Harvey 1884, p. 98; [Mennes and Smith] 1650, sig. K7v.

158 Howell 1642, p. 181.

159 Jordan 1641, sig. $\mathrm{C2}^{\mathrm{r}}$.

160 Churchyard 1593, pp. 165-166.

$161 O D N B$. It was publicly burned, and 29 booksellers were fined for buying it.

162 [Rowlands] 1600, sigs. $\mathrm{A2}^{\mathrm{r}}{ }^{\mathrm{B}}, \mathrm{B1}^{\mathrm{r}}, \mathrm{D}_{2}{ }^{\mathrm{r}}$; Geertz 1973, pp. $5^{-6 .}$ 
In the carriage of the body when walking, it was not the cringe which observers noted so much as the propensity to bend over backwards and stride along, bursting with self-importance. Joseph Hall's young master 'stifly strits [...] trapped in the new-found brauerie'. Overbury's traveller revealed his patent exhibitionism when his very 'gate cryes, Behold me'; more memorably, Brathwaite pictured such a one walking as if made in 'Wainescot'. ${ }^{163}$ In none of these instances was the strut attributable to any foreign influence in particular, so it is conceivable that they were making a point more of his excessive vainglory than of anything else. Still, it all forms part of the battery of attack upon these national anomalies. Others were more explicit: the jaundiced earl detected Spanish courtly manners lurking behind the Englishman who 'jetteth strouting'; that such a one then proceeds to make 'a dish-cloath of his owne Countrey in comparison of Spaine' was perhaps only to be expected. He took no pride in his own: his very body 'spoke' of the pride of Habsburg Spain. Meanwhile, something of Dekker's habitual prejudices rubbed off on a comment made by the character of Fortunatus, a disillusioned traveller, to the effect that Italy was behind the whole phenomenon of public bombast.

Fantasticke complement stalkes up and downe,

Trickt in out-landish Fethers, all his words

His lookes, his oathes, are all ridiculous

All apish, childish, and Italianate. ${ }^{164}$

Too much display, too much posturing, too much 'staged' behaviour went against the grain of every value that these public moralists sought to endorse. They despised excess very heartily.

In the opinion of these satirists, societal pedagogues, and polemicists, it will have become clear by now that nowhere are we nearer to caricature than in the portrayal of such self-imposed distortions and deformities of face and body, and that neither the traveller's nor the courtier's body could be said to speak English in any meaningful sense. Their gestures came not from within, but were shamelessly borrowed from a multiplicity of contexts and cobbled together in a vulgarly theatrical performance which was designed to 'move others to imitate his postures', something that made him more of a public menace than a harmless private oddity for those

163 [Hall] 1598, p. 61; Overbury 1616, sig. D1r; [Brathwaite] 1631b, p. 152. See also [Rowlands] 1600, sig. $\mathrm{C}_{7}^{\mathrm{r}}$ for reference to the 'swaggering' gait of the returned traveller. For a possible explanation of this manner of walking see below pp. 110-111.

164 Nashe 1594b, sig. L4 ${ }^{\text {; }}$ [Dekker] 1600, sig. E2 ${ }^{\mathrm{r}}$. 
with strongly contrasting perspectives. 'But what is it which makes him Complete?' Brathwaite mused. 'It is not a scrude face, an artfull Cringe, or an Italionate ducke that deserues so exquisite a title' but only virtue itself. Nothing but that would make a man complete, let alone completely English. ${ }^{165}$

Upon considering the convergence of evidence, it is plausible to argue that certain ways of speaking English and presenting oneself amounted, for many, to a way of being English, or, for that matter, falling short of being English. The positive construction regarded plainness not simply in a narrow linguistic frame of reference, but as a moral tool with which to face down contrary opinions and worrying contemporary trends. The negative construction focused on figures who blurred the normative contours in their various ways; these could not be entirely disassociated from England because of their birth, but critics found ways of questioning their legitimacy, undermining their status and depicting them as transgressors. Speech was not, however, the only site where a gambit was made for a native plainness. Fashion was another such area and just as speech was said to clothe reality, it is no surprise to learn that clothing too was thought to speak.

165 [Brathwaite] 1631b, p. 151; [Brathwaite] 1631a, p. 97. 